Published in final edited form as:

J Med Chem. 2005 April 7; 48(7): 2589-2599.

\title{
Lipopolysaccharide Sequestrants: Structural Correlates of Activity and Toxicity in Novel Acylhomospermines
}

\author{
Kelly A. Millera, E.V.K. Suresh Kumarb, Stewart J. Wood ${ }^{\mathrm{a}}$, Jens R. Cromera, Apurba Dattab, \\ and Sunil A. David ${ }^{\star a}$ \\ a Department of Medicinal Chemistry, University of Kansas, Life Sciences Research Laboratories, 1501 \\ Wakarusa Drive, Lawrence, KS - 66049
}

b Malott Hall, 1251 Wescoe Hall Drive, Lawrence, KS - 66045

\begin{abstract}
Lipopolysaccharides (LPS), otherwise termed 'endotoxins', are outer-membrane constituents of Gram-negative bacteria. Lipopolysaccharides play a key role in the pathogenesis of 'Septic Shock', a major cause of mortality in the critically ill patient. Therapeutic options aimed at limiting downstream systemic inflammatory processes by targeting lipopolysaccharide do not exist at the present time. We have defined the pharmacophore necessary for small molecules to specifically bind and neutralize LPS and, using animal models of sepsis, have shown that the sequestration of circulatory LPS by small molecules is a therapeutically viable strategy. In this paper, the interactions of a series of acylated homologated spermine compounds with lipopolysaccharide (LPS) have been characterized. The optimal acyl chain length for effective sequestration of LPS was identified to be $\mathrm{C}_{16}$ for the mono-acyl compounds. The most promising of these compounds, 4e, binds LPS with an $\mathrm{ED}_{50}$ of $1.37 \mu \mathrm{M}$. Nitric oxide production in murine J774A.1 cells, as well as TNF- $\alpha$ in human blood, are inhibited in a dose-dependent manner by $\mathbf{4 e}$ at concentrations orders of magnitude lower than toxic doses. Administration of $\mathbf{4 e}$ to o-galactosamine-sensitized mice challenged with supralethal doses of LPS provided significant protection against lethality. Potent anti-endotoxic activity, low toxicity, and ease of synthesis render this class of compounds candidate endotoxin-sequestering agents of potential significant therapeutic value.
\end{abstract}

\section{Keywords}

Endotoxin; Lipopolysaccharide; Sepsis; Shock; Lipopolyamines; Acylhomospermines

\section{Introduction}

\begin{abstract}
Endotoxins, or lipopolysaccharides (LPS), the predominant structural component of the outer membrane of Gram-negative bacteria,1 play a pivotal role in septic shock, a syndrome of systemic toxicity which occurs when the body's defense mechanisms are compromised or overwhelmed, or as a consequence of antibiotic chemotherapy of serious systemic infections
\end{abstract}

E-mail address: sdavid@ku.edu

CORRESPONDING AUTHOR FOOTNOTE: Sunil A. David, 145E Bldg B, University of Kansas Life Sciences Research Laboratories, 1501 Wakarusa Drive, Lawrence, KS - 66049, Tel: 785-330-4316; Fax: 785-330-4332

BRIEFS: Novel acylhomospermines were found to be potent, yet nontoxic lipopolysaccharide-sequestering agents likely to be useful in the prophylaxis of Gram-negative septic shock.

SUPPORTING INFORMATION PARAGRAPH: ${ }^{1} \mathrm{H}$ and ${ }^{13} \mathrm{C}$ NMR spectra of key intermediate compounds, elemental analyses of all key target compounds, and additional experimental data. 
(Gram-negative sepsis).2 Gram-negative sepsis is the number one cause of deaths in the intensive care unit, 3 accounting for more than 200,000 fatalities in the US annually.4

The presence of LPS in the systemic circulation causes a widespread activation of the innate immune response 5; 6 leading to the uncontrolled production of numerous inflammatory mediators, including tumor necrosis factor- $\alpha$ (TNF- $\alpha$ ), interleukin- $1 \beta$ (IL-1 $\beta$ ), and interleukin-6 (IL-6), primarily by cells of the monocyte/macrophage lineage, $7 ; 8$ as well as others, such as nitric oxide produced by the endothelial cell,9;10 which, in concert, act to cause a frequently fatal systemic inflammatory response, 11 termed 'septic shock'. The toxic moiety of LPS is its structurally conserved glycolipid component called Lipid A, 12 which is composed of a hydrophilic, bis-phosphorylated diglucosamine backbone, and a hydrophobic domain of 6 (E. coli) or 7 (Salmonella) acyl chains12 ( Fig. 1). We have determined the pharmacophore necessary for the neutralization of lipid A13 by small molecules requires two protonatable positive charges separated by a distance of $\sim 14 \AA$, enabling ionic $\mathrm{H}$-bonds between the cationic groups and the lipid A phosphates; in addition, appropriately positioned pendant hydrophobic functionalities are required to further stabilize the resultant complexes via hydrophobic interactions with the polyacyl domain of lipid A (for a recent review, see Ref. 14). These structural requisites are exemplified in the lipopolyamines, which are of particular interest because they are active in vitro and afford protection in animal models of Gram-negative sepsis, are synthetically easily accessible, and, importantly, are nontoxic, on account of their degradation to physiological substituents (spermine and fatty acid).15;16 A careful evaluation of structure-activity relationships in these compounds would be crucial in further iterations of designing potent analogues, and in their preclinical development as potential LPS-sequestering agents. The detailed studies on acylhomospermines that we report in this paper address two questions: (i) what is the optimal hydrophobic chain length for effective anti-endotoxic activity; (ii) are symmetrical bis-acyl spermines more effective than mono-acyl compounds. Our results indicate that a carbon number of 14-16 is optimal in mono-acyl spermines which are, in general, as potent as their bis-homologs and, in addition, show less surface activity (lower nonspecific cytotoxicity) and possess physical properties that are better suited for parenteral administration.

\section{Results and Discussion \\ Synthesis of acylhomospermines}

The synthesis of the desired mono-acyl homospermine derivatives under study is depicted in Scheme 1. Following reported procedures, commercially available spermine $\mathbf{1}$ was converted to the corresponding strategically protected homospermine derivative $\mathbf{2}$ in high yield.17-19 The free amino functionality of the compound $\mathbf{2}$ was acylated with various commercially available long chain aliphatic acids/acid derivatives under standard conditions, providing the corresponding mono- $N$-acylated pentamine derivatives 3a-f. While the compounds $\mathbf{3 b}$-c were acylated using the corresponding acid chlorides, the higher chain length analogs $\mathbf{3 d - f}$ were synthesized via EDCI mediated coupling between $\mathbf{4}$ and the corresponding carboxylic acids. Finally, removal of the Boc-protecting groups with excess trifluoroacetic acid, concentration of the reaction mixture under vacuum, and trituration of the resulting residue with diethyl ether resulted in the desired tetrakis(trifluoroacetyl)ammonium salts of the $N$-monoacyl homospermine derivatives 4a-f as white/off white amorphous solids in moderate to good yields. The assigned structure and purity of the products were confirmed by NMR $\left({ }^{1} \mathrm{H}\right.$ and ${ }^{13} \mathrm{C}$ ), mass spectroscopy and elemental analyses.

Following a similar reaction strategy as in Scheme 1, selective protection of both the terminal primary amino groups of spermine $\mathbf{1}$ as the corresponding bis-trifluoroacetamide, followed by Boc-protection of the two secondary amino groups and subsequent deblocking of the primary amines resulted in the $N^{2}, N^{3}$-di-Boc-spermine 5 in near quantitative yield (Scheme 2).

Homologation at both the free amino terminals was accomplished via Michael addition of the 
amines with acrylonitrile followed by Boc-protection of the resulting secondary amines to give the tetra-Boc-protected amino nitrile derivative $\mathbf{6}$. Hydrogenation of the nitrile groups of $\mathbf{6}$ under standard conditions provided the corresponding hexaamine derivative $\mathbf{7}$ in good yield. The free primary amino groups of $\mathbf{7}$ were subjected to acylation with various long chain aliphatic acids, and the adducts were treated with excess trifluoroacetic acid to remove the Bocprotecting groups. Removal of excess reagent under high vacuum and trituration of the residue with diethyl ether afforded the desired trifluoroacetic acid salts of $N^{1}, N^{6}$-diacyl-bis-

homospermine derivatives 8a-f as white/off white amorphous solids. The identity and purity of the products were verified by NMR $\left({ }^{1} \mathrm{H}\right.$ and $\left.{ }^{13} \mathrm{C}\right)$, mass spectroscopy and elemental analyses.

The monoacyl compounds 4a-f were all freely water soluble, but the bis compounds 8a-f were significantly less soluble, with $\mathbf{8 d - f}$ being practically insoluble in physiological buffers. Stock solutions $(5 \mathrm{mM})$ of all compounds were prepared in neat DMSO, and diluted out in buffer in the assays that are described below.

\section{Affinity of binding to lipopolysaccharide}

We had previously investigated a number of classes of hydrophobic polyamines,14-16;2022 including DOSPER, a lipospermine analog23;24 with two centrally placed pendant oleoyl chains, 16 as well as a $C_{15}$ analog of 6.15 From these initial, exploratory studies we had noted that homologated monoacylhomospermine binds lipid A with higher affinity and antagonizes the toxicity of LPS with greater potency than DOSPER, and we hypothesized that this could be attributable to steric hindrance in the case of DOSPER, and that terminally placed hydrophobic group(s) may obviate steric problems. This class of compounds is synthetically easily accessible and, importantly, expected to be nontoxic on account of being comprised of metabolically inert polyamine and fatty acid fragments and are, therefore, attractive drug candidates. It was thus of interest to systematically examine the effect of the number (mono versus bis) and length of the acyl chains, on binding affinity and biological activity. We first examined quantitatively the binding affinities of the homologated acylhomospermines to LPS using a rapid and robust high-throughput fluorescence displacement assay described recently. 25 The assay, in its entirety, consists of three automated steps: (i) in-plate serial dilution of compounds; (ii) addition of a mixture of LPS and BODIPY-TR-cadaverine; and (iii) recording end-point fluorescence intensity at a fixed wavelength $(620 \mathrm{~nm})$ in a plate reader. The addition of test compounds results in de-quenching of LPS-bound BC fluorescence, manifesting in emission intensity enhancements. The apparent binding affinities of the compounds, computed from displacement curves, are shown in Table 1 . We confirmed the validity of binding affinity $\left(\mathrm{ED}_{50}\right)$ obtained from fluorescence displacement data by performing isothermal titration calorimetry (ITC) experiments on several of the compounds that were freely soluble in aqueous buffers (data not shown). For instance, the interaction of $\mathbf{4} \mathbf{e}$ with LPS is exothermic and enthalpically driven $\left(\Delta \mathrm{H}:-17.02 \mathrm{kcal} \mathrm{mole}^{-1}, \Delta \mathrm{S}:-27.8 \mathrm{cal} \mathrm{mole}^{-1} \mathrm{~K}^{-1}\right)$, yielding a dissociation constant $\left(\mathrm{K}_{\mathrm{D}}\right)$ of $1.21 \mu \mathrm{M}$, which is in excellent agreement with the $\mathrm{ED}_{50}$ value of $1.37 \mu \mathrm{M}$ obtained from fluorescence experiments ( Table 1). A striking difference in binding affinities was observed between the mono- and bis-acyl compounds ( Table 1). 4a, with an acetyl substituent, binds very weakly, whereas all other $\left(\mathrm{C}_{8}-\mathrm{C}_{18}\right)$ compounds bind LPS with virtually identical affinities. The observation that $\mathbf{4 a}$ would be a weak binder was anticipated, given that we had earlier established that a hydrophobic group was necessary for optimal binding to the lipid A moiety of LPS.14-16;20-22;25-27 In contrast, a clear inverse correlation between binding affinity and acyl chain length is observed with the bis-acyl homologated acylhomospermines, with 8a $\left(\right.$ bis $\left.-\mathrm{C}_{8}\right)$ displaying an $\mathrm{ED}_{50}$ of $0.325 \mu \mathrm{M}$, a value that was even more favorable than that of polymyxin $\mathrm{B}(1.2 \mu \mathrm{M})$, the reference compound in all experiments. Although we were initially surprised by this somewhat counterintuitive result, as pointed out earlier, we observed that the longer homologs (8c-f) were progressively less water-soluble and were precipitating out of solution when the compound stocks in DMSO were being diluted out 
in aqueous buffer. The consequences of poor solubility were also manifested in in vivo experiments (see below)

\section{In vitro endotoxin neutralizing activity}

Murine, but not human monocytes, produce measurable quantities of nitric oxide (NO), an important surrogate marker of immune activation by bacterial products. 28 In vitro NO inhibition assays have proven to be a reliable and rapid primary biological screen for identifying anti-LPS compounds.14 Mouse J774A.1cells were exposed to $10 \mathrm{ng} / \mathrm{ml} \mathrm{LPS}$, with or without graded concentrations of the compounds. The dose-dependent inhibition of $\mathrm{NO}$ (measured as nitrite), and 50\% inhibitory concentration $\left(\mathrm{IC}_{50}\right)$ values for $\mathrm{NO}$ release are listed in Table 1. For the mono-acyl compounds, the shortest $\left(\mathrm{C}_{1}\right)$ analog, $\mathbf{4 a}$, is practically bereft of inhibitory activity, as expected, with an $\mathrm{IC}_{50}$ of $171.4 \mu \mathrm{M}$. The $\mathrm{C}_{8}(\mathbf{4 b})$ and $\mathrm{C}_{9}$ analogs $(\mathbf{4 c})$ are weak, with $\mathrm{IC}_{50} \mathrm{~s}$ of 52.5 , and $23.5 \mu \mathrm{M}$, respectively. However, the higher $\left(\mathrm{C}_{14-18}\right)$ mono-acyl compounds (4d-f) are all active with comparable potencies (3.7-4.3 $\mu \mathrm{M})$, suggesting that a long-chain acyl group with a carbon number of 14-18 is necessary for optimal neutralization ( Fig. 2). Among the bis-acyl compounds, the bis- $\mathrm{C}_{11}$ analog $(\mathbf{8 c})$ is most active $\left(\mathrm{IC}_{50}: 1.44\right.$ $\mu \mathrm{M}$ ), and longer chain-lengths are correlated with progressively lower affinities ( Fig. 2), probably a consequence of poor solubility. In all of these experiments, care was taken to verify that the inhibition of NO was not due to cytotoxic effects of the test compounds, using the XTT assay (data not shown).

The uncontrolled production of proinflammatory cytokines such as TNF- $\alpha$, IL-1 $\beta$, and IL-6 in response to circulatory LPS plays a central role in the pathogenesis of human septic shock.7 We therefore also examined the activity of these compounds in a whole-blood cytokine release assay.29;30 The multiplexed cytokine detection system that we used measures six cytokines concurrently from each sample. As controls, we used phorbol myristate acetate (PMA; $100 \mathrm{ng} /$ $\mathrm{ml})$ plus ionomycin $(1 \mu \mathrm{M})$, or PMA plus phytohemagglutinin $(2 \mu \mathrm{g} / \mathrm{ml})$ as non-LPS stimuli. None of the test compounds inhibited TNF- $\alpha$, IL-6, or IL-8 appreciably up to concentrations of $20 \mu \mathrm{M}$, verifying that the inhibition observed with LPS stimulation was a consequence of sequestration by the compounds. The $\mathrm{IC}_{50}$ values for LPS-induced TNF- $\alpha$ inhibition listed in Table 1 indicate that the dependence of TNF- $\alpha$ inhibition on the carbon number for both the mono- and bis-acyl compounds is very similar to that observed with NO inhibition ( Fig. 2). However, unlike in the NO inhibition data, the long-chain mono-acyl homospermine compounds (4d-f) show higher activity in inhibiting TNF- $\alpha$ in human whole blood than $\mathbf{8 a}$, the most potent of the bis series ( Fig. 2). We surmised that this discrepancy could also be a result of differential bioavailability arising from disparities in aqueous solubilities of the monoand bis- compounds. Serum albumin is a known carrier protein for otherwise insoluble ligands. 31;32 It appeared possible that a greater fraction of the more insoluble bis analogs would be protein-bound, thus reducing the concentration of free compound to sequester LPS. We therefore wished to test whether differences in in vivo bioavailability may alter the biological outcome. Consequently, we tested $8 \mathbf{a}$ and $8 \mathbf{c}$ in addition to $4 \mathbf{e}$ in the mouse model of LPSinduced lethality (see below).

\section{Correlation of binding affinity and in vitro biological activity}

Binding to LPS is a necessary, but not sufficient requisite for biological neutralization of endotoxic activity. For example, polymyxin B (PMB; decapeptide) and its nonapeptide derivative (PMBN) bind LPS with comparable affinities, but PMBN is virtually devoid of neutralizing activity.14 Furthermore, although the BC fluorescent probe displacement assay is an excellent rapid-throughput method to screen for LPS-binding molecules, $\mathrm{ED}_{50}$ values obtained from this assay are heavily weighted for electrostatic interactions between LPS and its ligand,21 and is not an accurate reporter of hydrophobic interactions. 14 We have previously shown this to be a crucial determinant of biological neutralization.14 The identification of 
provisional 'hits' with the $\mathrm{BC}$ high-throughput screen in our laboratory is therefore always confirmed in the murine NO assay. With this caveat in mind, although we did not expect a perfect correlation, it was of interest to compare the NO and TNF- $\alpha$ inhibition profiles with binding affinities observed with this congeneric series of compounds. As can be seen in Fig. 3 , with the exception of $\mathbf{4 a}$, all of the other $\mathbf{8}$ series mono-acyl compounds bind LPS with $\mathrm{ED}_{50}$ values between $\sim 1-2 \mu \mathrm{M}$, while only the longer acyl chain compounds (4d-f) are biologically active, indicating that the fluorescence assay does not discriminate adequately between high-affinity binders and high-potency neutralizers. Similar trends had also been observed with acyl chain lengths in cationic lipopeptides.33 This result emphasizes the necessity of employing a biological primary screen in tandem with the displacement assay in order to derive reliable structure-activity relationships in LPS-sequestering compounds. In contrast, there is an apparent linear correlation between $\mathrm{ED}_{50}$ and neutralization potency for the bis-acyl $\mathbf{8}$ series. This is simply a consequence of the poor solubility of the $\mathbf{8}$ homologs. Free aqueous concentrations of $\mathbf{8}$ are progressively retarded with increasing chain length, diminishing binding and, consequently, neutralization. It is noteworthy that these differences are clearly manifested in the outcomes of in vivo studies (see below). Physical properties such as solubility will likely affect the pharmacokinetics and pharmacodynamics of these compounds significantly, and will have to be taken into account early in the rational design and development of subsequent generations of potential anti-sepsis drugs.

\section{Toxicity}

The affinity of binding of a drug to its target becomes of crucial importance when nonspecific binding to pharmacologically irrelevant targets results in adverse effects. However, low affinity can be overcome simply by administering larger doses of the drug, by virtue of mass action affects. This is clinically realizable only when the toxicity profile (therapeutic index) is favorable. Considerations of toxicity therefore supervene, and sometimes supplant those of other pharmacological properties, particularly in the therapy of the critically-ill patient. A key consideration in the design of the compounds we have presented in this paper is the minimization of toxicity by specifically incorporating hydrolytic lability (acyl linkage) as well as the use of physiological, metabolically inert building blocks (spermine and fatty acid), a classical strategy in "soft drug" design.34;35 Members of the lipopolyamine class are of low toxicity to mammalian cells, and are being approved by the FDA for human use for gene transfection as safe alternatives to viral vectors.36;37 Indeed, our earlier work on DOSPER demonstrated that this compound was nontoxic to mice at concentrations well above therapeutic doses.16 However, both the $\mathbf{4}$ and $\mathbf{8}$ series are cationic amphipaths; in particular, the $\mathbf{8}$ series are analogous to "Gemini surfactants", so named after their twin-headed structures, 38 and could, possibly, display nonspecific cytotoxicity because of membrane-perturbing activity. We thought it prudent to characterize the surface activity of these compounds, correlate it to in vitro cytotoxicity, and carefully examine if these would have adverse consequences in vivo, prior to commencing animal experiments. As expected, the 'Gemini'like $8 \mathbf{a}$ and $\mathbf{8 b}$ (measured in 5\% DMSO to ensure solubility; the higher homologs were insoluble and could not be tested), are indeed considerably surface active (data not shown). For the 4 series (all of which were freely soluble in 5\% DMSO), there is a distinct correlation between acyl chain length and surface tension-lowering activity, as could be expected, with homologs with longer acyl chains being more surface active. We sought to quantitatively correlate surface activity and cell lysis first in highly diluted (1:1000; diluted in physiological saline), aged human whole blood. In this assay, erythrocytes become exquisitely susceptible to membrane damage and lysis, not only because of increased osmotic fragility of the erythrocytes due to depleted $\mathrm{Na}^{+} \mathrm{K}^{+}$ATPase activity, 39 but also due to the absence of 'buffering' effects of plasma proteins. The hemolytic activity of the $\mathbf{4}$ series mono-acyl compounds were found to correlate closely with their surface activity, a relationship that was not quite so straightforward for the bis-acyl $\mathbf{8}$ series because of the inferior solubility of the latter compounds (data not shown). 
The pronounced hemolytic activity of $\mathbf{4 f}$ and $\mathbf{4 e}(100 \%$ hemolysis at $1-5 \mu \mathrm{M})$ occasioned concern, and we questioned if the results of this assay employing deliberately exaggerated erythrocytic fragility were physiologically relevant; that is, if these compounds would likely cause intravascular hemolysis in vivo if administered parenterally. The hemolytic activities of these compounds were therefore reexamined using human whole blood and, to our relief, we observed significant hemolysis starting to occur only at millimolar concentrations (Fig. 4, top panel). In these latter experiments, melittin, an $\alpha$-helical 26-residue hemolytic peptide isolated from bee venom,40;41 caused hemolysis at low micromolar concentrations. Hypothesizing that the abrogation of hemolysis in whole blood was a consequence of binding of the otherwise surface active compounds to plasma proteins, we retested the effects of $\mathbf{4 e}$ and $\mathbf{4 f}$ on diluted, washed human erythrocytes, as described previously, in the absence, and presence of physiological concentrations of human serum albumin. The presence of $650 \mu \mathrm{M}$ albumin completely abolished the hemolytic activity of both these compounds (Fig. 4, bottom panel), indicating that a large fraction of these compounds was bound to albumin and that the proteinbound form was unlikely to exert toxicity. Indeed ongoing experiments with related compounds show no demonstrable dermal toxicity, neither acute nor chronic, when administered subcutaneously to mice at concentrations as high as $10 \mathrm{mg} / \mathrm{ml}$ (manuscripts in preparation).

\section{Protection against endotoxin-induced lethality in mice}

We elected to characterize the protective effects of $4 \mathbf{e}$, the most potent compound in the human TNF- $\alpha$ inhibition assay, $\mathbf{8 a}$, which was most active in inhibiting NO release in murine J774A. 1 cells, and $8 \mathbf{c}$, which was of lower potency than either $4 \mathbf{e}$ or $8 \mathbf{a}$ in both assays. A wellestablished animal model of LPS-induced lethality in mice sensitized by $\mathrm{D}$-galactosamine was used.42;43 A supralethal dose (twice the dose causing 100\% lethality) of $200 \mathrm{ng} / \mathrm{mouse}$ was administered intraperitoneally (i.p.) to groups of 5 mice sensitized with ${ }_{\text {D-galactosamine, along }}$ with concurrent, separate i.p. injections of graded doses of compound, and lethality was observed at $24 \mathrm{~h}$. The highly soluble $\mathbf{4 e}$ was dissolved in saline. The poor solubility of $\mathbf{8 a}$ and $\mathbf{8 c}$ necessitated the administration in 50\% DMSO. As is evident from Table 2, a clear doseresponse is observed, with $\mathbf{4 e}$ affording complete (statistically significant) protection at the 100 or $200 \mu \mathrm{g} /$ mouse dose, and partial protection at the $50 \mu \mathrm{g}$ dose. Both the bis-compounds are inferior to $\mathbf{4 e}$, (Table 2) underlining the importance of favorable pharmacodynamics properties enabling adequate plasma concentrations of free drug to effectively sequester LPS.

In our earlier studies on DOSPER, 16 we had observed that the temporal window of protection was very short. DOSPER had to be administered concurrent with the LPS challenge, and significant mortality resulted when the compound was given even 15 minutes prior to LPS. This was attributed to the extreme hydrolytic susceptibility to serum esterases of the orthoester linkages of the oleoyl groups, 16 and it was of interest if the amide-linked acylhomospermines would display a longer plasma half-life, thus affording a longer timewindow of protection. It is evident from the time-course experiment (Table 3 ) that $\mathbf{4 e}$ is indeed apparently much longer-lived, with near-complete protection evident when the compound is administered $6 \mathrm{~h}$ prior to LPS challenge (Table 3 ). In a few cohorts, we observed that this time window of protection was $4 \mathrm{~h}$ when $4 \mathrm{e}$ was administered intravenously (i.v.), and was $8 \mathrm{~h}$ when given subcutaneously, signifying a depot effect and prolonged release into systemic circulation in the latter experiments (data not shown). Mention was made earlier that one of the heuristics that we have used in developing potential anti-LPS compounds is to 'design-in' metabolic lability. The consequence of lability of a molecule is, of course, poor pharmacokinetic behavior because of rapid elimination from circulation, a situation that would be unacceptable for an orally bioavailable drug for the treatment of a chronic condition. However, rapid clearance, per se, is not of concern in the setting of an intensive care unit. For instance, sodium nitroprusside, used in the management of malignant hypertension has a $t_{1 / 2}$ of a few seconds. Administered i.v., the low $t_{1} / 2$ is actually useful in titrating the hypotensive effect on a minute- 
by-minute basis. In the therapy of a critically-ill patient in septic shock, an ideal regimen would be a rapid i.v. bolus infusion to achieve rapid plasma levels followed by a constant infusion to maintain an optimal drug concentration. We are presently examining analogs with alkylated spermines, as well as compounds with the hydrophobic functionalities in ester, urea, and carbamate linkages, in order to optimize pharmacokinetics, while retaining low toxicity. It is to be noted that $4 \mathrm{e}$ is without effect if administered $1 \mathrm{~h}$ following LPS challenge. The result of this time-course experiment is most instructive in that it suggests that if LPS-sequestering compounds, such as the acylhomospermines, are ever to find utility in the clinic, they will have to be used as prophylactic agents, rather than to treat sepsis once the inflammatory cascades are already set in motion. This may indeed be feasible and, indeed desirable, since not only have many of the therapeutic strategies that target downstream processes such as blockade of TNF- $\alpha$ or IL- $1 \beta$ have failed,44;45 but also because the predisposing factors for septic shock are very well recognized.46;47

In summary, we have described in this paper a detailed characterization of the endotoxinbinding and -neutralizing properties of a synthetically easily accessible class of nontoxic acylhomospermines. It is gratifying that considerably potent, and yet nontoxic analogs have been identified in the early phases of development. Can greater binding affinity and specificity be achieved without incurring the cost of additional toxicity or unfavorable physical properties? One possible approach to addressing the question of augmenting affinity is to test the hypothesis whether incorporating optimally placed $\mathrm{H}$-bond/donor atoms would serve to maximize interactions with the lipid A backbone.14;21 We are currently examining these questions in compounds with novel non-polyamine scaffolds.

\section{Experimental Section}

\section{Chemistry}

All of the solvents and reagents used were obtained commercially and used as such unless noted otherwise. Moisture or air sensitive reactions were conducted under argon atmosphere in oven dried $\left(120^{\circ} \mathrm{C}\right)$ glass apparatus. THF was distilled from sodium benzophenone ketyl, while dichloromethane was distilled over calcium hydride, prior to use. Solvents were removed under reduced pressure using standard rotary evaporators. Flash column chromatography was carried out using Silica gel 60 (230-400 mesh), while thin layer chromatography (tlc) was carried out on Silica Gel HLF, pre-coated glass plates. All yields reported refer to isolated material judged to be homogeneous by tlc and NMR spectroscopy. Unless noted otherwise, NMR spectra were recorded with the chemical shifts $(\delta)$ reported in ppm relative to $\mathrm{Me}_{4} \mathrm{Si}$ (for ${ }^{1} \mathrm{H}$ ) and $\mathrm{CDCl}_{3}$ (for ${ }^{13} \mathrm{C}$ ) or DMSO-d 6 (for ${ }^{13} \mathrm{C}$ ) as internal standards respectively.

\section{N1-Acetyl-(N4, N9, N13, N16-tetra-tert-butoxycarbonyl)-1, 16-diamino-4, 9, 13-triaza- hexadecane (3a)}

To a solution of compound $217-19(0.24 \mathrm{~g}, 0.36 \mathrm{mmol})$ in anhydrous methylene chloride (8 $\mathrm{mL})$ at $0{ }^{\circ} \mathrm{C}$ were added pyridine $(0.14 \mathrm{~g}, 1.8 \mathrm{mmol})$, acetic anhydride $(0.18 \mathrm{~g}, 0.18 \mathrm{mmol})$ and a catalytic amount of DMAP. The reaction mixture was stirred well for $10 \mathrm{~h}$ at room temperature. After removal of solvent, the residue was dissolved in ethyl acetate $(25 \mathrm{ml})$ and washed with water $(10 \mathrm{~mL} \times 3)$ followed by brine $(10 \mathrm{~mL})$. The organic layer was dried over $\mathrm{Na}_{2} \mathrm{SO}_{4}$, filtered and concentrated under reduced pressure. The resulting viscous liquid was purified by flash column chromatography (hexanes/EtOAc $=1: 1$ ) to afford the $B o c$-protected mono-acylated derivative $3 \mathrm{a}(0.21 \mathrm{~g}, 85 \%)$ as a viscous liquid. ${ }^{1} \mathrm{H}$ NMR $\left(400 \mathrm{MHz}, \mathrm{CDCl}_{3}\right)$ $\delta 1.36-1.42 \mathrm{~s}(\mathrm{~m}, 40 \mathrm{H}), 1.60-1.69$ (br m, 6H), $1.94(\mathrm{~s}, 3 \mathrm{H}), 3.1-3.23$ (br m, 16H); ${ }^{13} \mathrm{C} \mathrm{NMR}$ $\left(100.6 \mathrm{MHz}, \mathrm{CDCl}_{3}\right) \delta 23.5,26.0,26.1,27.6,28.5,28.6,35.7,37.4,43.4,43.8,44.3,44.9$, $46.9,78.9,79.5,79.9,155.5,156.2,156.4,170.37$; MS (FAB) calcd. for $\mathrm{C}_{35} \mathrm{H}_{67} \mathrm{~N}_{5} \mathrm{O}_{9} \mathrm{~m} / 2$ 701.4 , found $702.4(\mathrm{MH})^{+}$. 


\section{General procedure for the synthesis of compounds 3b-c}

To a solution of $2(0.24 \mathrm{~g}, 0.36 \mathrm{mmol})$ in anhydrous pyridine $(5 \mathrm{~mL})$ at $0{ }^{\circ} \mathrm{C}$ were added the respective acid chlorides (5 eq.) $\left[\mathrm{RCOCl}: \mathrm{R}=\mathrm{C}_{8} \mathrm{H}_{17}, \mathrm{C}_{9} \mathrm{H}_{19}\right.$ and $\mathrm{C}_{11} \mathrm{H}_{23}$ respectively] and a catalytic amount of DMAP. The reaction mixture was stirred well for $10 \mathrm{~h}$ at room temperature followed by quenching the reaction by addition of water $(15 \mathrm{~mL})$. The resulting solution was diluted with ethyl acetate $(50 \mathrm{ml})$, organic layer separated and washed sequentially with icecold $10 \% \mathrm{HCl}$ solution ( $20 \mathrm{~mL} \times 2)$, saturated aq. $\mathrm{NaHCO}_{3}$ solution $(20 \mathrm{~mL}$ x 3$)$, water (20 $\mathrm{mL})$ and brine $(20 \mathrm{~mL})$. The organic layer was dried over $\mathrm{Na}_{2} \mathrm{SO}_{4}$ and concentrated. The resulting Boc-protected mono-acylated derivatives $3 \mathbf{b}-\mathbf{c}$ ( $62 \%$ and $66 \%$ crude yield) were dried under high vacuum overnight and used as such for the next reaction.

\section{General procedure for the synthesis of compounds 3d-f}

To a solution of compound $2(0.30 \mathrm{mmol})$ in anhydrous THF $(5 \mathrm{~mL})$ at $0{ }^{\circ} \mathrm{C}$ were added the respective carboxylic acid (4 eq.) $\left[\mathrm{RCOOH}: \mathrm{R}=\mathrm{C}_{14} \mathrm{H}_{29}, \mathrm{C}_{16} \mathrm{H}_{33}, \mathrm{C}_{18} \mathrm{H}_{37}\right.$, respectively] and EDCI (4 eq.). The resulting mixture was stirred at room temperature for $10 \mathrm{~h}$. After removal of solvent, the residue was taken up in ethyl acetate $(25 \mathrm{ml})$ and washed sequentially with water $(10 \mathrm{~mL} \times 3)$, saturated aq. $\mathrm{NaHCO}_{3}$ solution $(20 \mathrm{~mL}$ x 2) and brine $(10 \mathrm{~mL})$. The organic layer was dried over $\mathrm{Na}_{2} \mathrm{SO}_{4}$ and solvent removed under reduced pressure. The resulting viscous liquids were purified by flash column chromatography (hexanes/EtOAc $=1: 1$ ) to obtain the Boc-protected mono-acylated polyamines 3d-f.

\section{N1-Pentadecanoyl-(N4, N9, N13, N16-tetra-tert-butoxycarbonyl)-1, 16-diamino-4, 9, 13- triazahexadecane $(3 d)$}

Viscous oil; yield $82 \% ;{ }^{1} \mathrm{H}$ NMR (400 MHz, $\mathrm{CDCl}_{3}$ ) $\delta 0.87$ (br t, J = 6.8 Hz, 3H), $1.22-1.31$ (m, 24H), 1.4-1.51 (m, 39H), 1.59-1.78 (br m, 7H), 2.17 (t, 2H, J = 6.8 Hz), 3.08-3.27 (br m, $16 \mathrm{H}) ;{ }^{13} \mathrm{C}$ NMR $\left(100.6 \mathrm{MHz}, \mathrm{CDCl}_{3}\right) \delta 14.3,22.9,25.7,26.0,27.8,28.6,28.7,29.1,29.5$, 29.6, 29.7, 29.8, 29.9, 32.1, 35.5, 37.1, 43.4, 44.9, 46.9, 79.3, 79.6, 80.0, 155.6, 156.3, 173.5; MS (FAB) calcd. for $\mathrm{C}_{48} \mathrm{H}_{93} \mathrm{~N}_{5} \mathrm{O}_{9} \mathrm{~m} / \mathrm{z} 883.7$, found $884.6(\mathrm{MH})^{+}$.

\section{N1-Heptadecanoyl-(N4, N9, N13, N16-tetra-tert-butoxycarbonyl)-1, 16-diamino-4, 9, 13-} triazahexadecane $(3 e)$

Viscous oil; yield $86 \% ;{ }^{1} \mathrm{H}$ NMR $\left(400 \mathrm{MHz}, \mathrm{CDCl}_{3}\right) \delta 0.87(\mathrm{t}, J=7.3 \mathrm{~Hz}, 3 \mathrm{H}), 1.24-1.28$ (m, 29H), 1.43-1.46 (m, 38H), 1.62-1.85 (br m, 7H), 2.15-2.17 (m, 2H), 3.05-3.32 (br m, $16 \mathrm{H}) ;{ }^{13} \mathrm{C} \mathrm{NMR}\left(100.6 \mathrm{MHz}, \mathrm{CDCl}_{3}\right) \delta 14.3,22.8,26.0,27.7,28.6,28.7,29.1,29.5,29.6$, 29.7, 29.8, 29.9, 32.1, 35.5, 37.1, 43.4, 44.9, 46.9, 79.3, 79.6, 80.0, 155.6, 156.3, 173.5; MS (FAB) calcd. for $\mathrm{C}_{50} \mathrm{H}_{97} \mathrm{~N}_{5} \mathrm{O}_{9} \mathrm{~m} / z$ 911.7, found $912.4(\mathrm{MH})^{+}$.

\section{N1-Nonadecanoyl-(N4, N9, N13, N16-tetra-tert-butoxycarbonyl)-1, 16-diamino-4, 9, 13- triazahexadecane (3f)}

Viscous liquid; yield $82 \%$; ${ }^{1} \mathrm{H}$ NMR $\left(400 \mathrm{MHz}, \mathrm{CDCl}_{3}\right) \delta 0.87$ (br t, $\left.J=6.8 \mathrm{~Hz}, 3 \mathrm{H}\right), 1.24$ 1.28 (m, 34H), 1.43-1.46 (m, 36H), 1.62-1.80 (br m, 8H), 2.15-2.17 (m, 2H), 3.05-3.32 (br $\mathrm{m}, 16 \mathrm{H}) ;{ }^{13} \mathrm{C} \mathrm{NMR}\left(100.6 \mathrm{MHz}, \mathrm{CDCl}_{3}\right) \delta 14.3,22.8,26.0,27.8,28.6,28.7,29.5,29.6,29.7$, 29.8, 29.9, 32.1, 35.5, 37.2, 43.4, 44.9, 46.9, 76.9, 79.1 , 79.6, 80.0, 155.6, 156.3, 156.6, 173.5; MS (FAB) calcd. for $\mathrm{C}_{52} \mathrm{H}_{101} \mathrm{~N}_{5} \mathrm{O}_{9} \mathrm{~m} / z$ 939.7, found $940.9(\mathrm{MH})^{+}$.

\section{General procedure for the synthesis of compounds 4a-f}

Boc-protected mono-acylated derivatives 3a-f were dissolved in $8 \mathrm{ml}$ of trifluoroacetic acid and stirred for 8 hours at ambient temperature. Excess solvent was removed under reduced pressure and the residue dried under high vacuum overnight. The resulting sticky residue was 
washed thoroughly with diethyl ether to obtain the desired compounds $\mathbf{4 a - f}$ as off white flaky solids.

N1-Acetyl-1, 16-diamino-4, 8, 13-triazahexadecane-tetra-(trifluoroacetic acid)salt (4a)

Yield $82 \%$; ${ }^{1} \mathrm{H}$ NMR (400 MHz, DMSO) $\delta 1.58-1.75(\mathrm{~m}, 4 \mathrm{H}), 1.80(\mathrm{~s}, 3 \mathrm{H}), 1.83-2.01(\mathrm{~m}$, $4 \mathrm{H}$ ), 2.82-3.04 (br m, 16H). 3.08-3.15 (m, 2H), 8.07 (br s, 4H), 8.87 (br s, 6H); ${ }^{13} \mathrm{C} \mathrm{NMR}$ $\left(100.6, \mathrm{MHz}, \mathrm{DMSO}-\mathrm{d}_{6}\right) \delta 22.5,22.6,23.8,36.1,43.8,46.1,158.8,169.7$; MS (FAB) calcd. for $\mathrm{C}_{15} \mathrm{H}_{35} \mathrm{~N}_{5} \mathrm{O} \mathrm{m} / z$ 301.4, found $302.4(\mathrm{MH})^{+}$(freebase).

N1-Nonanoyl-1, 16-diamino-4, 8, 13-triazahexadecane-tetra-(trifluoroacetic acid) salt (4b)

Yield 70\%; ${ }^{1} \mathrm{H}$ NMR (400 MHz, $\left.\mathrm{D}_{2} \mathrm{O}\right) \delta 0.85$ (br s, 3H), 1.17 (br s, 10H), 1.55-1.65 (m, 2H), 1.76 (br s, 4H), 1.85-1.95 (m, 2H), 2.05-2.18 (m, 4H), 2.22-2.26 (m, 2H), 3.05-3.20 (bm, $14 \mathrm{H}), 3.26-3.29(\mathrm{~m}, 2 \mathrm{H}) ;{ }^{13} \mathrm{C}$ NMR $\left(100.6 \mathrm{MHz}, \mathrm{DMSO}_{-} \mathrm{d}_{6}\right) \delta 14.4,22.5,22.8,23.0,24.2$, 25.7, 26.4, 28.9, 29.0, 29.1, 31.6, 35.8, 36.0, 36.7, 44.4, 44.5, 45.2, 46.7, 159.3, 174.2; MS (FAB) calcd. for $\mathrm{C}_{22} \mathrm{H}_{49} \mathrm{~N}_{5} \mathrm{O} \mathrm{m} / 2,301.4$, found $300.7(\mathrm{MH})^{+}$(freebase).

N1-Decanoyl-1, 16-diamino-4, 8, 13-triazahexadecane-tetra-(trifluoroacetic acid) salt (4c)

Yield 56\%; ${ }^{1} \mathrm{H}$ NMR (400 MHz, DMSO-d 6 ) $\delta 0.85$ (br t, $\left.J=6.8 \mathrm{~Hz}, 3 \mathrm{H}\right), 1.23$ (bs, $12 \mathrm{H}$, $\left.\mathrm{CH}_{2}\right), 1.45-1.53(\mathrm{~m}, 2 \mathrm{H}), 1.61(\mathrm{~m}, 4 \mathrm{H}), 1.68-1.74(\mathrm{~m}, 2 \mathrm{H}), 1.85-1.96(\mathrm{~m}, 4 \mathrm{H}), 2.06(\mathrm{t}, J=7.4$ $\mathrm{Hz}, 2 \mathrm{H}$ ), 2.85-2.98 (br m, 14H), 3.08-3.15 (m, 2H), 7.92 (br m, 4H), 8.60-8.74 (br m, $6 \mathrm{H}) ;{ }^{13} \mathrm{C}$ NMR (100.6 MHz, DMSO-d 6 ) $\delta 13.9,22.1,22.4,22.6,24.3,25.2,26.4,28.7,28.8$, 28.9, 31.2, 35.2, 35.5, 36.1, 43.8, 43.9, 44.9, 46.5, 159.3, 159.4, 174.5; MS (FAB) calcd. for $\mathrm{C}_{23} \mathrm{H}_{51} \mathrm{~N}_{5} \mathrm{O} \mathrm{m} / 2$ 413.7, found $414.5(\mathrm{MH})^{+}$(freebase).

N1-Pentadecanoyl-1, 16-diamino-4, 8, 13-triazahexadecane tetra-(trifluoroacetic acid) salt (4d)

Yield $81 \%$; ${ }^{1} \mathrm{H}$ NMR (400 MHz, DMSO) $\delta 0.85$ (t, $\left.J=6.8 \mathrm{~Hz}, 3 \mathrm{H}\right), 1.22(\mathrm{br} \mathrm{s}, 22 \mathrm{H}), 1.42-$ $1.52(\mathrm{~m}, 2 \mathrm{H}), 1.60-1.75(\mathrm{~m}, 6 \mathrm{H}), 1.87-1.95(\mathrm{~m}, 4 \mathrm{H}), 2.05(\mathrm{t}, J=7.4 \mathrm{~Hz}, 2 \mathrm{H}), 2.85-3.02(\mathrm{br}$ $\mathrm{m}, 14 \mathrm{H}$ ), 3.07-3.11 (m, 2H), 7.99 (br s, 4H), 8.89 (br m, 6H); ${ }^{13} \mathrm{C}$ NMR (100.6 MHz, DMSO$\left.\mathrm{d}_{6}\right) \delta 13.9,22.1,22.6,25.2,28.7,28.8,28.9,29.0,32.3,43.8,158.9,159.2,173.2 ;$ MS (FAB) calcd. for $\mathrm{C}_{28} \mathrm{H}_{61} \mathrm{~N}_{5} \mathrm{O} \mathrm{m} / z$ 483.7, found $484.6(\mathrm{MH})^{+}$(freebase).

N1-Heptadecanoyl-1, 16-diamino-4, 8, 13-triazahexadecane tetra-(trifluoroacetic acid) salt (4e)

Yield 78\%; ${ }^{1} \mathrm{H}$ NMR (400 MHz, DMSO-d 6 ) $\delta 0.85(\mathrm{t}, J=6.8 \mathrm{~Hz}, 3 \mathrm{H}), 1.23(\mathrm{br} \mathrm{s}, 26 \mathrm{H}), 1.45-$ 1.50 (m, 2H), 1.61-1.69 (br s, 4H), 1.70-1.77 (m, 3H), 1.88-1.92 (m, 4H), 2.05 (t, $J=7.4 \mathrm{~Hz}$, 2H), 2.80-3.01 (br m, 14H), 3.07-3.11 (m, 2H), 7.91-7.99 (br m, 4H), 8.66-8.79 (br m, $6 \mathrm{H}) ;{ }^{13} \mathrm{C}$ NMR (100.6 MHz, DMSO-d 6 ) $\delta 13.9,22.1,22.4,22.6,23.8,25.2,26.1,28.7,28.8$, 28.9, 29.0, 31.3, 35.3, 35.5, 36.2, 43.8, 43.9, 44.7, 46.1, 158.7, 172.7; MS (FAB) calcd. for $\mathrm{C}_{30} \mathrm{H}_{65} \mathrm{~N}_{5} \mathrm{O} \mathrm{m} / 2.511 .7$, found $512.7(\mathrm{MH})^{+}$(freebase).

N1-Nonadecanoyl-1, 16-diamino-4, 8, 13-triazahexadecane tetra-(trifluoroacetic acid) salt (4f) Yield 82\%; ${ }^{1} \mathrm{H}$ NMR (400 MHz, DMSO-d 6 ) $\delta 0.85(\mathrm{t}, J=6.6 \mathrm{~Hz}, 3 \mathrm{H}), 1.22(\mathrm{br} \mathrm{s}, 32 \mathrm{H}), 1.45-$ 1.51 (m, 2H), 1.60-1.78 (br m, 4H), 1.88-1.98 (m, 4H), 2.05 (t J=7.4 Hz, 2H), 2.85-3.06 (br $\mathrm{m}, 14 \mathrm{H}$ ), 3.09-3.12 (m, 2H), 7.99 (br s, 4H), 8.73-8.86 (br m, 6H); ${ }^{13} \mathrm{C}$ NMR (100.6 MHz, DMSO-d $\left._{6}\right) \delta 13.9,22.1,22.5,24.3,22.6,25.28,26.4,28.7,28.8,28.9,29.0,31.3,35.4,35.5$, 36.2, 43.8, 43.9, 44.9, 46.1, 158.4, 156.5, 172.7; MS (FAB) calcd. for $\mathrm{C}_{32} \mathrm{H}_{69} \mathrm{~N}_{5} \mathrm{O} \mathrm{m} / z$. 539.7, found $540.8(\mathrm{MH})^{+}$(freebase). 
(N4, N9-Di-tert-butoxycarbonyl)-1, 12-diamino-4, 9-diazadodecane (5)

To a solution of spermine $\mathbf{1}(1.0 \mathrm{~g}, 4.95 \mathrm{mmol})$ in methanol $(70 \mathrm{~mL})$ at $-78^{\circ} \mathrm{C}$, ethyl trifluoroacetate $(1.40 \mathrm{~g}, 9.90 \mathrm{mmol})$ was added drop wise over $30 \mathrm{~min}$ and the solution stirred for another $30 \mathrm{~min}$. The temperature was increased to $0{ }^{\circ} \mathrm{C}$ and an excess of di-tertbutyldicarbonate $(3.17 \mathrm{~g}, 14.85 \mathrm{mmol})$ in methanol $(10 \mathrm{~mL})$ was added over $10 \mathrm{~min}$. The reaction was then warmed to $25^{\circ} \mathrm{C}$ and stirred for further $17 \mathrm{~h}$. The trifluoroacetate protecting groups were then removed in situ by increasing the $\mathrm{pH}$ of the solution to above 11 with conc. aq. ammonia and then stirred at $25^{\circ} \mathrm{C}$ for $15 \mathrm{~h}$. After removal of solvent under vacuum, the residue was purified by flash column chromatography $\left(\mathrm{CH}_{2} \mathrm{Cl}_{2}-\mathrm{MeOH}\right.$-conc. aq. $\mathrm{NH}_{3}$ 50:10:1) to afford the title compound 7 as a colorless viscous oil $(1.92 \mathrm{~g}, 97 \%)$. ${ }^{1} \mathrm{H}$ NMR (400 MHz, $\left.\mathrm{CDCl}_{3}\right) \delta 1.43$ and $1.49(2 \mathrm{~s}, 22 \mathrm{H}), 1.66$ (br s, $\left.4 \mathrm{H}\right), 2.89$ (br s, 4H), 3.17-3.29 (2 br s, 8H), 6.27 (br s, $4 \mathrm{H}$, exchangeable with $\left.\mathrm{D}_{2} \mathrm{O}\right) ;{ }^{13} \mathrm{C}$ NMR $\left(100.6 \mathrm{MHz}, \mathrm{CDCl}_{3}\right) \delta$ 23.3, 25.3, 25.7, 27.4, 28.0, 28.3, 28.5, 28.7, 29.5, 31.7, 32.4, 33.2, 38.9, 39.3, 43.7, 44.2, 46.2, 46.5, 56.4, 76.9, 79.1, 81.0, 82.4, 155.4, 155.6; MS (FAB) calcd. for $\mathrm{C}_{20} \mathrm{H}_{42} \mathrm{~N}_{4} \mathrm{O}_{4} \mathrm{~m} / z$. 402.2, found $403.1(\mathrm{MH})^{+}$.

(N3, N7, N12, N16-Tetra-tert-butoxycarbonyl)-1, 18-dicyano-3, 7, 12, 16-tetrazaocta-decane (6)

To a solution of compound $\mathbf{5}(1.0 \mathrm{~g}, 2.48 \mathrm{mmol})$ in methanol $(50 \mathrm{~mL})$ was added acrylonitrile $(0.26 \mathrm{~g}, 5 \mathrm{mmol})$ and stirred at room temperature for $15 \mathrm{~h}$. After removal of solvent under high vacuum, the crude bis-nitrile derivative $(1.2 \mathrm{~g}, 95 \%)$ was dissolved in $\mathrm{CH}_{2} \mathrm{Cl}_{2}(50 \mathrm{~mL})$ followed by addition of a solution of di-tert-butyl dicarbonate (1.05 g, $4.8 \mathrm{mmol}$ ) in $\mathrm{CH}_{2} \mathrm{Cl}_{2}$ $(10 \mathrm{~mL})$. The resulting solution was stirred for $90 \mathrm{~min}$ at ambient temperature, concentrated in vacuo and purified by flash column chromatography (hexanes-EtOAc $=3: 2$ ) to give compound $6(1.12 \mathrm{~g}, 64 \%)$ as a viscous oil; ${ }^{1} \mathrm{H}$ NMR $\left(400 \mathrm{MHz}, \mathrm{CDCl}_{3}\right) \delta 1.45$ and $1.47(2 \mathrm{~s}$, $42 \mathrm{H}), 1.72-1.79(\mathrm{~m}, 4 \mathrm{H}), 2.55-2.68(\mathrm{~m}, 4 \mathrm{H}), 3.08-3.20(\mathrm{br} \mathrm{s}, 6 \mathrm{H}), 3.21-3.30(\mathrm{~m}, 4 \mathrm{H}), 3.46-$ $3.51(\mathrm{~m}, 4 \mathrm{H}) ;{ }^{13} \mathrm{C} \mathrm{NMR}\left(100.6 \mathrm{MHz}, \mathrm{CDCl}_{3}\right) \delta 17.0,17.6,25.6,26.0,28.4,28.5,43.5,44.0$, 44.6, 45.5, 46.6, 47.0, 79.5, 80.6, 154.7, 155.2, 155.5; MS (FAB) calcd. for $\mathrm{C}_{36} \mathrm{H}_{64} \mathrm{~N}_{6} \mathrm{O}_{8} \mathrm{~m} /$ z 708.4, found $709.5(\mathrm{MH})^{+}$.

(N4, N8, N13, N17-Tetra-tert-butoxycarbonyl)-1, 20-diamino-4, 8, 13, 17-tetrazaicosane (7)

A solution of bis-nitrile $6(0.9 \mathrm{~g}, 1.26 \mathrm{mmol})$ in glacial acetic acid $30 \mathrm{~mL}$ was hydrogenated over $\mathrm{Pd}(\mathrm{OH})_{2} / \mathrm{C}(0.9 \mathrm{~g})$ at $50 \mathrm{psi}$ hydrogen pressure for $2 \mathrm{~h}$. The catalyst was removed by filtration and the residue washed thoroughly with methanol. After concentrating the combined filtrate under vacuum, the residual oil was dissolved in ethylacetate $(100 \mathrm{~mL})$ and washed sequentially with $1 \mathrm{~N} \mathrm{NaOH}(50 \mathrm{~mL}$ x 2$)$ and water. After drying over $\mathrm{MgSO}_{4}$, the solution was concentrated and left under high vacuum overnight to afford compound $7(0.80 \mathrm{~g}, 97 \%)$ as a viscous solid. ${ }^{1} \mathrm{H}$ NMR $\left(400 \mathrm{MHz}, \mathrm{CDCl}_{3}\right) \delta 1.45(\mathrm{~s}, 42 \mathrm{H}), 1.62-1.73(\mathrm{~m}, 8 \mathrm{H}), 2.66(\mathrm{br}$ $\mathrm{s}, 4 \mathrm{H},), 3.15-3.26(\mathrm{~m}, 18 \mathrm{H}) ;{ }^{13} \mathrm{C} \mathrm{NMR}\left(100.6 \mathrm{MHz}, \mathrm{CDCl}_{3}\right) 25.6,28.5,28.6,38.7,43.8,44.9$, 46.7, 79.4, 79.6, 155.5; MS (FAB) calcd. for $\mathrm{C}_{36} \mathrm{H}_{72} \mathrm{~N}_{6} \mathrm{O}_{8} \mathrm{~m} / z, 716.5$, found $717.6(\mathrm{MH})^{+}$.

\section{General procedure for the synthesis of compounds 8a-f}

To a solution of compound $7(0.10 \mathrm{~g}, 0.15 \mathrm{mmol})$ in anhydrous THF $(5 \mathrm{~mL})$ at $0{ }^{\circ} \mathrm{C}$ was added the respective carboxylic acid (8 eq.) [RCOOH: $\mathrm{R}=\mathrm{C}_{8} \mathrm{H}_{17}, \mathrm{C}_{9} \mathrm{H}_{19}, \mathrm{C}_{10} \mathrm{H}_{21}, \mathrm{C}_{13} \mathrm{H}_{27}, \mathrm{C}_{15} \mathrm{H}_{31}$, $\mathrm{C}_{17} \mathrm{H}_{35}$ respectively) and EDCI (8 eq.) followed by stirring of the mixture for $10 \mathrm{~h}$ at room temperature. After removal of solvent, the residue was taken up in ethyl acetate $(25 \mathrm{ml})$ and washed sequentially with water $(10 \mathrm{~mL} \times 3)$, ice-cold $10 \% \mathrm{HCl}$ solution $(10 \mathrm{~mL} \times 2)$, saturated aq. $\mathrm{NaHCO}_{3}$ solution $(20 \mathrm{~mL} \times 2)$ and brine $(10 \mathrm{~mL})$. The organic layer was dried over $\mathrm{Na}_{2} \mathrm{SO}_{4}$, filtered and solvent evaporated under reduced pressure. The resulting Boc-protected bis-acylated polyamines were dried under high vacuum and dissolved in $8 \mathrm{ml}$ of dry trifluoroacetic acid and stirred at room temperature for 8 hours. Excess solvent was removed under reduced pressure and the residue left under high vacuum overnight. The resulting sticky 
residue was thoroughly washed with diethyl ether to obtain the desired compounds 8a-f as off white flaky solids.

N1, N20-Bis-nonanoyl-1, 20-diamino-4, 8, 13, 17-tetrazaicosane-tetra-(trifluoroacetic acid) salt (8a)

Yield 60\%; ${ }^{1} \mathrm{H}$ NMR (400 MHz, DMSO-d 6 ) $\delta 0.85(\mathrm{t}, J=7.2 \mathrm{~Hz}, 6 \mathrm{H}), 1.23(\mathrm{br} \mathrm{s}, 20 \mathrm{H}), 1.46-$ 1.51, (m, 4H), 1.62-1.68 (b s, 4H), 1.69-1.74 (m, 4H), 1.90-1.98 (m, 4H), 2.05 (t, $J=7.3 \mathrm{~Hz}$, 4H), 2.85-3.01 (br m, 16H), 3.08-3.12 (m, 4H), 7.98 (t, $J=5.6 \mathrm{~Hz}, 2 \mathrm{H}), 8.78$ and 8.93 (2s, $8 \mathrm{H}) ;{ }^{13} \mathrm{C}$ NMR $\left(125.7 \mathrm{MHz}, \mathrm{DMSO}-\mathrm{d}_{6}\right) \delta 14.3,22.4,22.8$, 25.6, 23.0, 25.6, 26.5, 29.0, 29.1, 31.6, 35.7, 35.9, 44.3, 46.5, 159.2, 173.1; MS (FAB) calcd. for $\mathrm{C}_{34} \mathrm{H}_{72} \mathrm{~N}_{6} \mathrm{O}_{2} m / z, 596.5$, found $597.7(\mathrm{MH})^{+}$(free base).

N1, N20-Bis-decanoyl-1, 20-diamino-4, 8, 13, 17-tetrazaicosane-tetra-(trifluoroacetic acid) salt (8b)

Yield 76\%; ${ }^{1} \mathrm{H}$ NMR $(500 \mathrm{MHz}$, DMSO-d 6 ) $\delta 0.85(\mathrm{t}, J=6.8 \mathrm{~Hz}, 6 \mathrm{H}), 1.23(\mathrm{br} \mathrm{s}, 24 \mathrm{H}), 1.46-$ $1.51(\mathrm{~m}, 4 \mathrm{H}), 1.63-1.75(\mathrm{~m}, 8 \mathrm{H}), 1.90-2.00(\mathrm{~m}, 4 \mathrm{H}), 2.06(\mathrm{t}, \mathrm{J}=7.40 \mathrm{~Hz}, 4 \mathrm{H}), 2.86-2.98$ (br $\mathrm{m}, 16 \mathrm{H}), 3.09-3.12(\mathrm{~m}, 4 \mathrm{H}), 7.98(\mathrm{t}, J=5.7 \mathrm{~Hz}, 2 \mathrm{H}), 8.75$ and $8.89,2 \mathrm{~s}, 8 \mathrm{H}) ;{ }^{13} \mathrm{C} \mathrm{NMR}(125.7$ MHz, DMSO-d $\left.\mathrm{d}_{6}\right) \delta 14.3,22.5,22.8,23.0,25.6,26.5,29.1,29.2,29.3,31.6,35.7,35.9,44.3$, 44.4, 45.1, 46.5, 159.2, 173.2; (FAB) calcd. for $\mathrm{C}_{36} \mathrm{H}_{76} \mathrm{~N}_{6} \mathrm{O}_{2} \mathrm{~m} / z$, 624.5, found 625.7 $(\mathrm{MH})^{+}$(free base).

N1, N20-Bis-dodecanoyl-1, 20-diamino-4, 8, 13, 17-tetrazaicosane-tetra-(trifluoro-acetic acid) salt (8c)

Yield 72\%; ${ }^{1} \mathrm{H}$ NMR (500 MHz, DMSO-d 6 ) $\delta 0.85(\mathrm{t}, J=6.8 \mathrm{~Hz}, 6 \mathrm{H}), 1.23$, (br s, 32H), 1.45$1.51(\mathrm{~m}, 4 \mathrm{H}), 1.65$ (b s, 4H), 1.68-1.75 (m, 4H), 1.91-1.98 (m, 4H), 2.05 (t, $J=7.3 \mathrm{~Hz}, 4 \mathrm{H})$, 2.86-3.01 (3m, 16H), 3.08-3.12 (m, 4H), $7.99(\mathrm{t}, J=5.7 \mathrm{~Hz}, 2 \mathrm{H}), 8.76$ and $8.90(2 \mathrm{~s}$, $8 \mathrm{H}) ;{ }^{13} \mathrm{C}$ NMR $(125.7 \mathrm{MHz}$, DMSO-d 6 ) $\delta 14.3,22.5,22.8,23.0,25.6,26.5,29.1,29.2,29.3$, 29.4, 29.4, 31.7, 35.7, 35.9, 44.3, 44.3, 45.1, 46.5, 159.1, 173.1; MS (FAB) calcd. for $\mathrm{C}_{40} \mathrm{H}_{84} \mathrm{~N}_{6} \mathrm{O}_{2} \mathrm{~m} / z, 680.5$, found $681.9(\mathrm{MH})^{+}$(free base).

N1, N20-Bis-pentdecanoyl-1, 20-diamino-4, 8, 13, 17-tetrazaicosane-tetra-(trifluoro-acetic acid) salt (8d)

Yield $48 \%$; ${ }^{1} \mathrm{H}$ NMR (400 MHz, DMSO-d 6 ) $\delta 0.85(\mathrm{t}, J=7.0 \mathrm{~Hz}, 6 \mathrm{H}), 1.23(\mathrm{br} \mathrm{s}, 44 \mathrm{H}), 1.40$ $1.51(\mathrm{~m}, 4 \mathrm{H}), 1.62-1.75(\mathrm{~m}, 8 \mathrm{H}), 1.89-1.99(\mathrm{~m}, 4 \mathrm{H}) 2.05$ (t, $J=7.4 \mathrm{~Hz}, 4 \mathrm{H}), 2.85-3.02$ (br m, $16 \mathrm{H}), 3.08-3.12(\mathrm{~m}, 4 \mathrm{H}), 7.99(\mathrm{t}, J=6.4 \mathrm{~Hz}, 2 \mathrm{H}), 8.68$ and $8.84(2 \mathrm{br} \mathrm{s}, 8 \mathrm{H}) ;{ }^{13} \mathrm{C} \mathrm{NMR}(100.6$ MHz, DMSO-d 6 ) $\delta 14.0,22.1,22.4,22.7,25.3,26.2,28.7,28.8,28.9,29.0,29.1,31.3,35.3$, 35.5, 43.9, 44.7, 46.1, 158.5, 172.8; MS (FAB) calcd. for $\mathrm{C}_{46} \mathrm{H}_{96} \mathrm{~N}_{6} \mathrm{O}_{2} \mathrm{~m} / 2,764.5$, found 765.8 $(\mathrm{MH})^{+}$(free base).

N1, N20-Bis-heptadecanoyl-1, 20-diamino-4, 8, 13, 17-tetrazaicosane-tetra-(trifluoro-acetic acid) salt (8e)

Yield $81 \% ;{ }^{1} \mathrm{H}$ NMR $\left(400 \mathrm{MHz}, \mathrm{DMSO}-\mathrm{d}_{6}\right) \delta 0.85(\mathrm{t}, J=6.9 \mathrm{~Hz}, 6 \mathrm{H}), 1.23(\mathrm{br} \mathrm{s}, 56 \mathrm{H}), 1.44-$ 1.5 (m, 4H), 1.60-1.72, m, 6H), 1.9-2.1 (br m, 8H), 2.82-3.15 (br m, 18H), 7.99 (m, 2H), 8.65 and $8.80(2 \mathrm{br} \mathrm{s}, 8 \mathrm{H}) ;{ }^{13} \mathrm{C}$ NMR $\left(125.7 \mathrm{MHz}, \mathrm{DMSO}_{-} \mathrm{d}_{6}\right) \delta 13.9,22.0,22.4,22.6,25.2,26.1$, 28.6, 28.7, 29.0, 31.2, 35.3, 35.4, 43.8, 43.9, 44.7. 46.0, 172.1; MS (FAB) calcd. for $\mathrm{C}_{50} \mathrm{H}_{104} \mathrm{~N}_{6} \mathrm{O}_{2} \mathrm{~m} / \mathrm{z}, 820.7$, found $821.9(\mathrm{MH})^{+}$(free base). 


\section{N1, N20-Bis-nonadecanoyl-1, 20-diamino-4, 8, 13, 17-tetrazaicosane tetra-(trifluoro-acetic} acid) salt (8f)

Yield $48 \% ;{ }^{1} \mathrm{H}$ NMR $(400 \mathrm{MHz}$, DMSO-d 6$) \delta 0.85(\mathrm{t}, J=6.9 \mathrm{~Hz}, 6 \mathrm{H}), 1.22(\mathrm{~s}, 62 \mathrm{H}), 1.42-$ $1.51(\mathrm{~m}, 4 \mathrm{H}),, 1.61-1.75(\mathrm{~m}, 8 \mathrm{H}), 1.90-2.00(\mathrm{~m}, 4 \mathrm{H}), 2.05(\mathrm{t}, J=7.4 \mathrm{~Hz}, 4 \mathrm{H}), 2.81-3.0(\mathrm{br} \mathrm{m}$, $14 \mathrm{H}), 3.05-3.13(\mathrm{~m}, 4 \mathrm{H}), 7.99(\mathrm{t}, \mathrm{J}=5.6 \mathrm{~Hz}, 2 \mathrm{H}), 8.75$ and $8.87(\mathrm{br} \mathrm{m}, 8 \mathrm{H}) ;{ }^{13} \mathrm{C} \mathrm{NMR}(100.6$ MHz, DMSO-d 6 ) 13.9, 22.1, 22.7, 23.0, 23.6, 25.2, 26.3, 27.5, 28.7, 28.8, 28.9, 29.0, 31.3, 35.3, 35.5, 36.7, 44.2, 44.81, 46.3, 53.3, 172.7; MS (FAB) calcd. for $\mathrm{C}_{54} \mathrm{H}_{112} \mathrm{~N}_{6} \mathrm{O}_{2} \mathrm{~m} / z, 877.1$, found $878.0(\mathrm{MH})^{+}$(free base).

\section{Rapid-throughput Fluorescence Displacement Assay for quantifying binding affinities to LPS}

The BODIPY-TR-cadaverine (BC; (5-(((4-(4,4-difluoro-5-(2-thienyl)-4-bora-3a,4a-diaza-sindacene-3-yl) phenoxy)acetyl)amino)pentylamine, hydrochloride; obtained from Molecular probes, Inc., Eugene, OR) displacement assay to quantify the affinities of binding of compounds to LPS has been described in detail recently. 25 This assay was performed in a rapid-throughput format as follows: the first column (16 wells) of a Corning Nonbinding Surface 384-well flat-bottom black fluorescence microplate contained 15 test compounds plus polymyxin B, all at $5 \mathrm{mM}$ in DMSO, and were serially diluted two-fold in $50 \mathrm{mM}$ Tris buffer, $\mathrm{pH} 7.4$, across the remaining 23 columns, achieving a final dilution of $0.596 \mathrm{nM}$ in a volume of $40 \mu$ l. Polymyxin B (PMB), a peptide antibiotic known to bind and neutralize LPS48 served as the positive control and reference compound for every plate, enabling the quantitative assessment of repeatability and reproducibility (CV and Z' factors) for the assay. Automated liquid handling was performed on a Precision 2000 automated microplate pipetting system, programmed using the Precision Power software, Bio-Tek Instruments Inc., VT, USA.

\section{Isothermal Calorimetry (ITC)}

ITC experiments were performed using a VP-ITC Microcalorimeter (Microcal Inc., MA, USA). A typical titration experiment involved 35 consecutive injections at $360 \mathrm{~s}$ intervals consisting of $3 \mathrm{ml}$ injections of E. coli 0111:B4 LPS into the sample cell (cell volume: 1.4119 $\mathrm{ml}$ ) containing the acylhomospermine compound, at $37^{\circ} \mathrm{C}$ in Tris buffer $(\mathrm{pH} 7.4,50 \mathrm{mM})$. The titration cell was stirred continuously at $310 \mathrm{rpm}$. Care was taken to ensure that both LPS and ligand were dissolved in the same buffer, and appropriate control experiments (LPS injected into buffer, BC injected into buffer) were performed. The resulting data were then analyzed using Microcal's ITC data analysis package, VP Viewer 2000, which uses the scientific plotting software, Origin 7 (Origin Lab. Corp., MA, USA).

\section{Nitric Oxide Assay}

Nitric oxide production was measured as total nitrite in murine macrophage J774A.1 cells using the Griess assay 49 as described previously. $16 \mathrm{~J} 774 \mathrm{~A} .1$ cells were plated at $\sim 10^{5} / \mathrm{ml}$ in a volume of $40 \mu 1 /$ well, in 384-well, flat-bottomed, cell culture treated microtiter plates and subsequently stimulated with $10 \mathrm{ng} / \mathrm{ml}$ lipopolysaccharide (LPS). Concurrent to LPS stimulation, serially diluted concentrations of test compounds were added to the cell medium and left to incubate overnight for $16 \mathrm{~h}$. Polymyxin B was used as reference compound in each plate. Positive- (LPS stimulation only) and negative-controls (J774A.1 medium only) were included in each experiment. Nitrite concentrations were measured by adding $40 \mu \mathrm{l}$ of supernatant to equal volumes of Griess reagents ( $50 \mu \mathrm{l} / \mathrm{well} ; 0.1 \%$ NED solution in $\mathrm{ddH}_{2} \mathrm{O}$ and $1 \%$ sulfanilamide, $5 \%$ phosphoric acid solution in $\mathrm{dd}_{2} \mathrm{O}$ ) and incubating for 15 minutes at room temperature in the dark. Absorbance at $535 \mathrm{~nm}$ was measured using a Molecular Devices Spectramax M2 multifunction plate reader (Sunnyvale, CA). Nitrite concentrations were interpolated from standard curves obtained from serially diluted sodium nitrite standards. 


\section{In vitro XTT cytotoxicity assay}

The determination of cell viability was accomplished by the addition of an XTT50 solution to J774A. 1 cultures treated with graded concentrations of the test compounds. Cell culture and plating procedures were performed as described previously for nitric oxide measurement. Cytotoxicity was measured the following day by the addition of $80 \mu \mathrm{l} /$ well XTT/Phenazine methosulfate (PMS) solution (XTT solution, $2 \mathrm{mM}$ in PBS, pH 7.4, pH adjusted to 6.0-6.5; PMS solution, $0.92 \mathrm{mg} / \mathrm{ml}$ in PBS, $\mathrm{pH} 7.4$; solutions mixed at a ratio of $8 \mathrm{ml}$ XTT solution to $200 \mu \mathrm{l}$ PMS solution) followed by an incubation time of $1.5 \mathrm{~h}$ at $37^{\circ} \mathrm{C}$. Absorbance was read at $490 \mathrm{~nm}$ with scatter correction at $690 \mathrm{~nm}$.

\section{Multiplexed cytokine assay ex vivo in human blood}

$100 \mu \mathrm{l}$ aliquots of fresh whole blood, anticoagulated with EDTA, obtained by venipuncture from healthy human volunteers with informed consent and as per guidelines approved by the Human Subjects Experimentation Committee, was exposed to an equal volume of $20 \mathrm{ng} / \mathrm{ml}$ of E. coli 0111:B4 LPS, with graded concentrations of test compounds diluted in saline for $4 \mathrm{~h}$ in a 96-well microtiter plate.29;51 The effect of the compounds on modulating cytokine production was examined using a FACSArray multiplexed flow-cytometric bead array (CBA) system (Becton-Dickinson-Pharmingen, San Jose, CA). The system uses a sandwich ELISAon-a-bead principle,52;53 and is comprised of 6 populations of microbeads that are spectrally unique in terms of their intrinsic fluorescence emission intensities (detected in the FL3 channel of a standard flow cytometer). Each bead population is coated with a distinct capture antibody to detect six different cytokines concurrently from biological samples (the human inflammation CBA kit includes TNF- $\alpha$, IL-1 $\beta$, IL-6, IL-8, IL-10, and IL-12p70). The beads are incubated with $30 \mu \mathrm{l}$ of sample, and the cytokines of interest are first captured on the bead. After washing the beads, a mixture of optimally paired second antibodies conjugated to phycoerythrin is added which then forms a fluorescent ternary complex with the immobilized cytokine, the intensity (measured in the FL2 channel) of which is proportional to the cytokine concentration on the bead. The assay was performed according to protocols provided by the vendor. Standard curves were generated using recombinant cytokines provided in the kit. The data were analyzed in the CBA software suite that is integral to the FACSArray system.

\section{Surface tension measurements and hemolytic activity}

Because the acylhomospermines are cationic amphipaths, these compounds are likely to have membrane-perturbing activity, which may be a principal manifestation of their toxicity. We therefore attempted to correlate their surface activity with hemolytic activity as has been reported recently.54 The surface activity of the compounds was measured via dynamic bubble pressure and surface age tensiometry55 using a Krüss PocketDyne instrument (Krüss GmbH, Hamburg, Germany). Samples were at $500 \mu \mathrm{M}$ concentration in $50 \mathrm{mM}$ Tris buffer, $\mathrm{pH} 7.4$ containing 5\% DMSO. The instrument was calibrated with water at $25^{\circ} \mathrm{C}(72 \mathrm{mN} / \mathrm{m})$ and surface tension values were recorded over a range of bubble surface ages from 100 to $1500 \mathrm{~ms}$ at $25^{\circ} \mathrm{C}$. Erythrocyte damage was measured using two different techniques. In the first, hemolysis was quantified using extremely diluted, aged human whole blood such that the effects of the compounds binding to plasma proteins would be negligible, and the hemolytic activity would be magnified because of increased osmotic fragility of the erythrocytes as a consequence of depleted $\mathrm{Na}^{+} \mathrm{K}^{+}$ATPase activity.39 Dilute erythrocyte suspensions were prepared by diluting one-week-old whole blood obtained by venipuncture from healthy human volunteers 1:1000 in isotonic $(0.9 \mathrm{~g} / 100 \mathrm{ml})$ saline solution to which was added graded doses of compound. Absorptimetric determination of hemoglobin released from such a dilute erythrocyte suspension was not reliable. The samples were therefore examined with a Beckman-Coulter Vi-Cell ${ }^{\mathrm{TM}}$ Cell Viability Analyzer (Beckman-Coulter, Hialeah, FL). This instrument implements an automated intravital trypan blue exclusion method using real-time 
automated video microscopy. Measurement parameters for erythrocytes were gated appropriately on control erythrocytes to specify thresholds of cell recognition and viability. Data on total number of cells $/ \mathrm{ml}$ and viable cells $/ \mathrm{ml}$ were collected through 50 captured images per sample with a counting accuracy of $+/-3 \%$. In order to examine the effect of plasma proteins on the surface activity, some of the experiments were repeated in the presence of nearphysiological concentrations of human serum albumin. Because it became apparent that the compounds were binding strongly to albumin, thereby resulting in an almost complete abrogation of hemolytic activity, it was of interest to examine the compounds under physiological conditions. The second method, consequently, was designed to examine the effects of the compounds on whole blood. $100 \mu \mathrm{l}$ of serially diluted compounds were mixed with an equal volume of fresh, undiluted, EDTA-anticoagulated human blood in a 96-well microplate using an automated liquid handler. After incubation at $37^{\circ} \mathrm{C}$ for $30 \mathrm{~min}$, the plates were centrifuged at $3000 \mathrm{RPM}$ for $10 \mathrm{~min}, 80 \mu \mathrm{l}$ of supernatants transferred to a fresh plate, and the amount of free hemoglobin released into the supernatant was quantified using absorptimetry at $570 \mathrm{~nm}$. In the latter assay, melittin, a potently hemolytic $\alpha$-helical bee venom peptide 41 was used as positive control.

\section{Mouse lethality experiments}

Female, outbred, 9- to 11-week-old CF-1 mice (Charles River, Wilmington, MA) weighing 22-28 $\mathrm{g}$ were used as described elsewhere. 16 The animals were sensitized to the lethal effects of LPS by d-galactosamine. $42 ; 43 ; 52$ The lethal dose causing $100 \%$ mortality $\left(\mathrm{LD}_{100}\right)$ dose for the batch of LPS used (E. coli 0111:B4; procured from Sigma) was first determined by administering ${ }_{\mathrm{D}}$-galactosamine $(800 \mathrm{mg} / \mathrm{kg})$ and LPS $(0,10,20,50,100,200 \mathrm{ng} / \mathrm{mouse})$ as a single injection intraperitoneally (i.p.) in freshly prepared saline to cohorts of five animals in a volume of $0.2 \mathrm{ml}$. The expected dose-response profile was observed in two independent experiments with all five mice receiving $100 \mathrm{ng}$ succumbing within $24 \mathrm{~h}$, establishing the $\mathrm{LD}_{100}$ dose to be $100 \mathrm{ng} /$ mouse. In experiments designed to test dose-response effects of the acylhomospermines in affording protection against LPS-induced lethality, mice received graded doses of compound diluted in saline, i.p. in one flank, immediately before a supralethal (200 ng) LPS challenge, which was administered as a separate i.p. injection into the other flank. Some animals also received test compounds subcutaneously or i.v. to observe differences in the degree and duration of protection; these experiments also served to verify that LPS was being sequestered systemically, and not just in situ, in the peritoneal cavity. In experiments in which the temporal window of protection was to be examined, a fixed dose of $200 \mu \mathrm{g} / \mathrm{mouse}$ of compound was administered at various times, before or after supralethal (200 ng/mouse) LPS challenge. Lethality was determined at $24 \mathrm{~h}$ post LPS challenge.

\section{Supplementary Material}

Refer to Web version on PubMed Central for supplementary material.

\section{Acknowledgements}

This work was supported from NIH grant 1R01 AI50107, and a First Award Grant from P20 RR015563 from the COBRE Program of the National Center for Research Resources and matching support from the State of Kansas, and the University of Kansas.

\section{References}

1. Rietschel ET, Kirikae T, Schade FU, Mamat U, Schmidt G, Loppnow H, Ulmer AJ, Zähringer U, Seydel U, Di Padova F, et al. Bacterial endotoxin: molecular relationships of structure to activity and function. FASEB J 1994;8:217-225. [PubMed: 8119492]

2. Hurley JC. Antibiotic-induced release of endotoxin. A therapeutic paradox. Drug Saf 1995;12:183195. [PubMed: 7619330] 
3. Gasche,Y.; Pittet,D.; and Sutter,P. Outcome and prognostic factors in bacteremic sepsis. In Clinical trials for treatment of sepsis. Sibbald, W. J. and Vincent, J. L. Eds.; Springer-Verlag: Berlin, 1995; pp $35-51$.

4. Centers for Diseases Control. Increases in national hospital discharge survey rates for septicemia United States, 1979-1987. MMWR 1990;39:31-34.

5. Ulevitch RJ. Molecular mechanisms of innate immunity. Immunol Res 2000;21:49-54. [PubMed: 10852101]

6. Ulevitch RJ, Tobias P. Recognition of gram-negative bacteria and endotoxin by the innate immune system. Curr Opin Immunol 1999;11:19-23. [PubMed: 10047547]

7. Dinarello CA. Cytokines as mediators in the pathogenesis of septic shock. Curr Top Microbiol Immunol 1996;216:133-165. [PubMed: 8791739]

8. Michie HR, Manogue KR, Spriggs DR, Revhaug A, O’Dwyer S, Dinarello CA, Cerami A, Wolff SM, Wilmore DW. Detection of circulating tumor necrosis factor after endotoxin administration. N Engl J Med 1988;318:1481-1486. [PubMed: 2835680]

9. Meyer J, Traber DL. Nitric oxide and endotoxin shock. Cardiovasc Res 1992;26:558. [PubMed: 1446327]

10. Wright CE, Rees DD, Moncada S. Protective and pathological roles of nitric oxide in endotoxin shock. Cardiovasc Res 1992;26:48-57. [PubMed: 1516112]

11. Bone RC. The sepsis syndrome. Definition and general approach to management. Clin Chest Med 1996;17:175-181. [PubMed: 8792059]

12. Raetz CRH, Whitfield C. Lipopolysaccharide endotoxins. Annu Rev Biochem 2002;71:635-700. [PubMed: 12045108]

13. David SA, Mathan VI, Balaram P. Interactions of linear dicationic molecules with lipid A: Structural requisites for optimal binding affinity. J Endotoxin Res 1995;2:325-336.

14. David SA. Towards a rational development of anti-endotoxin agents: novel approaches to sequestration of bacterial endotoxins with small molecules (Invited Review). J Molec Recognition 2001;14:370-387.

15. Blagbrough IS, Geall AJ, David SA. Lipopolyamines incorportaing the teraamine spermine bound to an alkyl chain , sequester bacterial lipopolysaccharide. Bioorg Med Chem Lett 2000;10:19591962. [PubMed: 10987426]

16. David SA, Silverstein R, Amura CR, Kielian T, Morrison DC. Lipopolyamines: novel antiendotoxin compounds that reduce mortality in experimental sepsis caused by gram-negative bacteria. Antimicrob Agents Chemother 1999;43:912-919. [PubMed: 10103199]

17. Blagbrough IS, Geall AJ. Practical synthesis of unsymmetrical polyamine amides. Tetrahedron Lett 1998;39:439-442.

18. Geall AJ, Blagbrough IS. Homologation of polyamines in the synthesis of lipospermine conjugates and related lipoplexes. Tetrahedron Lett 1998;39:443-446.

19. Jasys VJ, Kelbaugh PR, Nason DM, Phillips D, Rosnack KJ, Saccomano NA, Sroh JG, Volkmann RA. Isolation, structure elucidation, and synthesis of novel hydroxylamine-containing polyamines from the venom of Agelenopsis aperta spider. J Am Chem Soc 1990;112:6696-6704.

20. David SA, Bechtel B, Annaiah C, Mathan VI, Balaram P. Interaction of cationic amphiphilic drugs with lipid A: Implications for development of endotoxin antagonists. Biochim Biophys Acta 1994;1212:167-175. [PubMed: 8180242]

21. David SA, Mathan VI, Balaram P. Interactions of linear dicationic molecules with lipid A: Structural features that correspond to optimal binding affinity. J Endotoxin Res 1995;2:325-336.

22. David SA, Perez L, Infante MR. Sequestration of bacterial lipopolysaccharide by bis(args) gemini compounds. Bioorg Med Chem Lett 2002;12:357-360. [PubMed: 11814796]

23. Behr JP, Demeneix B, Loeffler JP, Perez-Mutul J. Efficient gene transfer into mammalian primary endocrine cells with lipopolyamine-coated DNA. Proc Natl Acad Sci USA 1989;86:6982-6986. [PubMed: 2780554]

24. Behr JP. Gene transfer with synthetic cationic amphiphiles: Prospects for gene therapy. Bioconjug Chem 1994;5:382-389. [PubMed: 7849066] 
25. Wood SJ, Miller KA, David SA. Anti-endotoxin agents. 1. Development of a fluorescent probe displacement method for the rapid identification of lipopolysaccharide-binding agents. Comb Chem High Throughput Screen 2004;7:239-249. [PubMed: 15134530]

26. Bhattacharjya S, David SA, Mathan VI, Balaram P. Polymyxin B nonapeptide: Conformations in water and in the lipopolysaccharide-bound state determined by two-dimensional NMR and molecular dynamics. Biopolymers 1997;41:251-265.

27. David SA, Awasthi SK, Wiese A, Ulmer AJ, Lindner B, Brandenburg K, Seydel U, Rietschel ET, Sonesson A, Balaram P. Characterization of the interactions of a polycationic, amphiphilic, terminally branched oligopeptide with lipid A and lipopolysaccharide from the deep rough mutant of Salmonella minnesota. J Endotoxin Res 1996;3:369-379.

28. Weisz A, Oguchi S, Cicatiello L, Esumi H. Dual mechanism for the control of inducible-type NO synthase gene expression in macrophages during activation by interferon- gamma and bacterial lipopolysaccharide. Transcriptional and post- transcriptional regulation. J Biol Chem 1994;269:8324-8333. [PubMed: 7510685]

29. Remick,D.G.; Newcomb,D.E.; and Friedland,J.S. Whole-blood assays for cytokine production. In Septic shock. Methods and protocols. Evans, T. J. Ed.; Humana Press: New Jersey, 2000;

30. Fennrich S, Fischer M, Hartung T, Lexa P, Montag-Lessing T, Sonntag HG, Weigandt M, Wendel A. Detection of endotoxins and other pyrogens using human whole blood. Dev Biol Standards 1999;101:131-139.

31. David SA, Balaram P, Mathan VI. Characterization of the interaction of lipid A and lipopolysaccharide with human serum albumin: implications for an endotoxin-carrier function for albumin. J Endotoxin Res 1995;2:99-106.

32. He XM, Carter DC. Atomic structure and chemistry of human serum albumin. Nature 1992;358:209215. [PubMed: 1630489]

33. Majerle A, Kidric J, Jerala R. Enhancement of antibacterial and lipopolysaccharide binding activities of a human lactoferrin peptide fragment by the addition of acyl chain. $\mathbf{J}$ Antimicrob Chemother 2003;51:1159-1165. [PubMed: 12697647]

34. Bodor N. Novel approaches to the design of safer drugs: Soft drugs and site-specific chemical delivery systems. Adv Drug Res 1984;13:255-331.

35. Bodor N, Buchwald P. Soft drug design: General principles and recent applications. Med Res Rev 2000;20:58-101. [PubMed: 10608921]

36. Nabel EG, Simari R, Yang Z, San H, Nabel GJ. In vivo gene transfer: a biological tool. Ann N Y Acad Sci 1997;811:289-292. [PubMed: 9186604]

37. Stephan DJ, Yang ZY, San H, Simari RD, Wheeler CJ, Felgner PL, Gordon D, Nabel GJ, Nabel EG. A new cationic liposome DNA complex enhances the efficiency of arterial gene transfer in vivo. Hum Gene Ther 1996;7:1803-1812. [PubMed: 8894672]

38. Menger FM, Keiper JS. Gemini surfactants. Angew Chem Int Ed Engl 2000;39:1906-1920. [PubMed: 10940980]

39. Nagini S, Selvam S. Biochemical indicators of membrane damage in the plasma and erythrocytes of rats fed the peroxisome proliferator di(2-ethylhexyl)phthalate. Med Sci Res 1997;25:119-121.

40. Bernard E, Faucon JF, Dufourcq J. Phase separations induced by melittin in negatively-charged phospholipid bilayers as detected by fluorescence polarization and differential scanning calorimetry. Biochimica et Biophysica Acta 1982;688:152-162. [PubMed: 7093270]

41. David SA, Mathan VI, Balaram P. Interaction of melittin with endotoxic lipid A. Biochim Biophys Acta 1992;1123:269-274. [PubMed: 1536865]

42. Freudenberg MA, Galanos C. Tumor necrosis factor alpha mediates lethal activity of killed Gramnegative abd Gram-positive bacteria in D-galactosamine- treated mice. Infect Immun 1991;59:21102115. [PubMed: 2037372]

43. Tracey KJ, Cerami A. Tumor necrosis factor, other cytokines and disease. Annu Rev Cell Biol 1993;9:317-343. [PubMed: 8280464]

44. Quezado ZMN, Banks SM, Natanson C. New strategies for combatting sepsis: the magic bullets missed the mark ... but the search continues. Trends Biotech 1995;13:56-63.

45. Zeni F, Freeman B, Natanson C. Anti-inflammatory therapies to treat sepsis and septic shock: A reassessment. Crit Care Med 1997;25:1097-1100. 
46. Bone RC. Gram-negative sepsis: a dilemma of modern medicine. Clin Microbiol Rev 1993;6:57-68. [PubMed: 8457980]

47. Opal SM, Yu RLJ. Antiendotoxin strategies for the prevetion and treatment of septic shock. New approaches and future directions. Drugs 1998;55:497-508. [PubMed: 9561340]

48. Morrison DC, Jacobs DM. Binding of polymyxin B to the lipid A portion of bacterial lipopolysaccharides. Immunochemistry 1976;13:813-818. [PubMed: 187544]

49. Green LC, Wagner DA, Glogowski J, Skipper PL, Wishnok JS, Tannenbaum SR. Analysis of nitrate, nitrite and [15-N] nitrate in biological fluids. Anal Biochem 1982;126:131. [PubMed: 7181105]

50. Roehm NW, Rodgers GH, Hatfield SM, Glasebrook AL. An improved colorimetric assay for cell proliferation and viability utilizing the tetrazolium salt XTT. J Immunol Methods 1991;142:257265. [PubMed: 1919029]

51. Fennrich S, Fischer M, Hartung T, Lexa P, Montag-Lessing T, Sonntag HG, Weigandt M, Wendel A. Detection of endotoxins and other pyrogens using human whole blood. Dev Biol Standards 1999;101:131-139.

52. Cook EB, Stahl JL, Lowe L, Chen R, Morgan E, Wilson J, Varro R, Chan A, Graziano FM, Barney NP. Simultaneous measurement of six cytokines in a single sample of human tears using microparticle-based flow cytometry: allergics vs. non-allergics. J Immunol Methods 2001;254:109_ 116. [PubMed: 11406157]

53. Funato Y, Baumhover H, Grantham-Wright D, Wilson J, Ernst D, Sepulveda H. Simultaneous measurement of six human cytokines using the Cytometric Bead Array System, a multiparameter immunoassay system for flow cytometry. Cytometry Res 2002;12:93-103.

54. Ross BP, Braddy AC, McGeary RP, Blanchfield JT, Prozkai L, Toth I. Micellar aggregation and membrane partitioning of bile salts, fatty acids, sodium dodecyl sulfate, and sugar-conjugated fatty acids: correlation with hemolytic potency and implications for drug delivery. Mol Pharmaceutics 2004;1:233-245.

55. Fainerman VB, Miller R. Maximum bubble pressure tensiometry--an analysis of experimental constraints. Adv Colloids Interface Sci 2004;108-109:287-301.

56. Wood SJ, Miller KA, David SA. Anti-endotoxin agents. 2. Pilot high-throughput screening for novel lipopolysaccharide-recognizing motifs in small molecules. Comb Chem High Throughput Screen 2004;7:733-743. [PubMed: 15578935] 


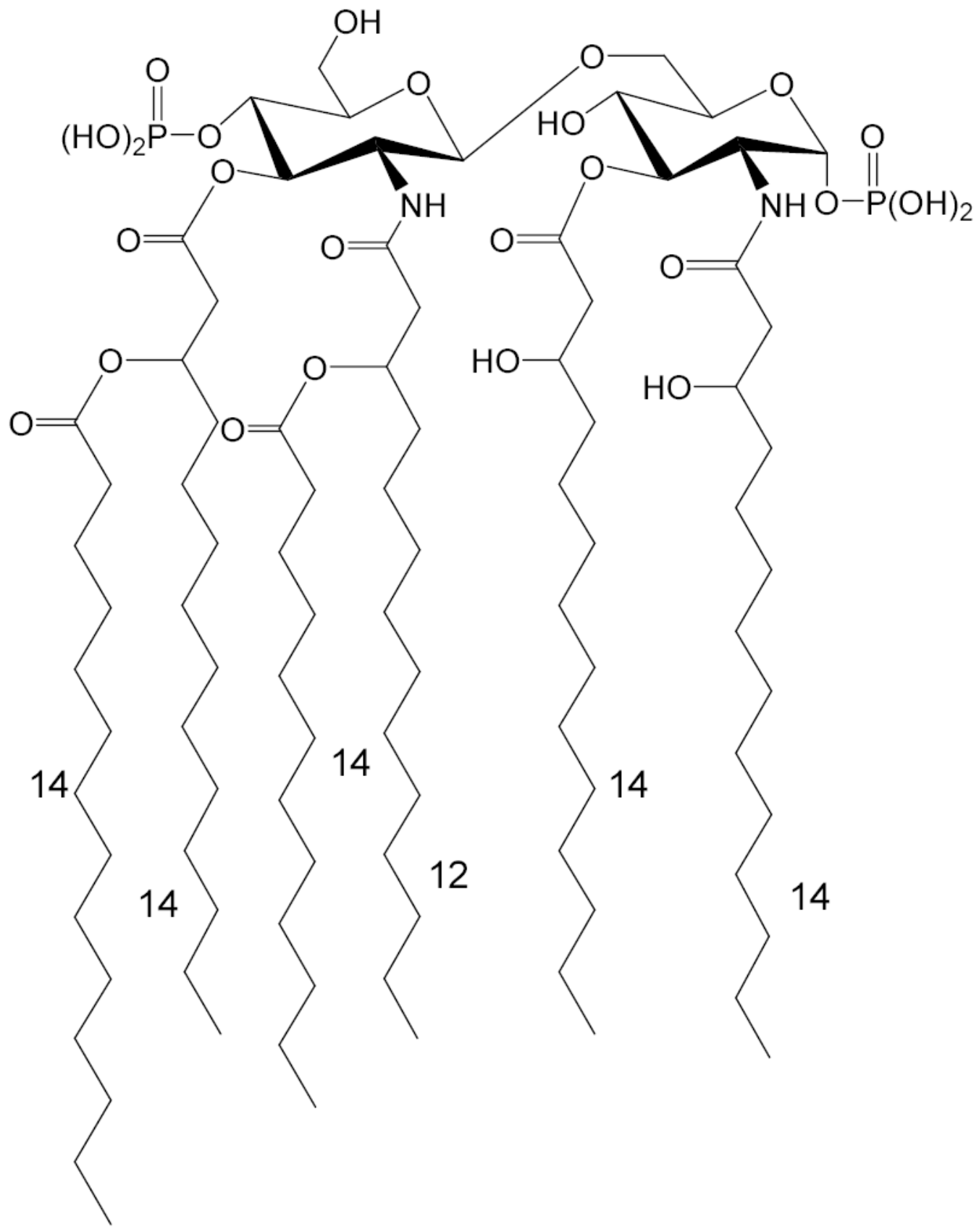

Figure 1.

Structure of Lipid A, the toxic moiety of bacterial lipopolysaccharide. Numbers indicate acyl chain length. 

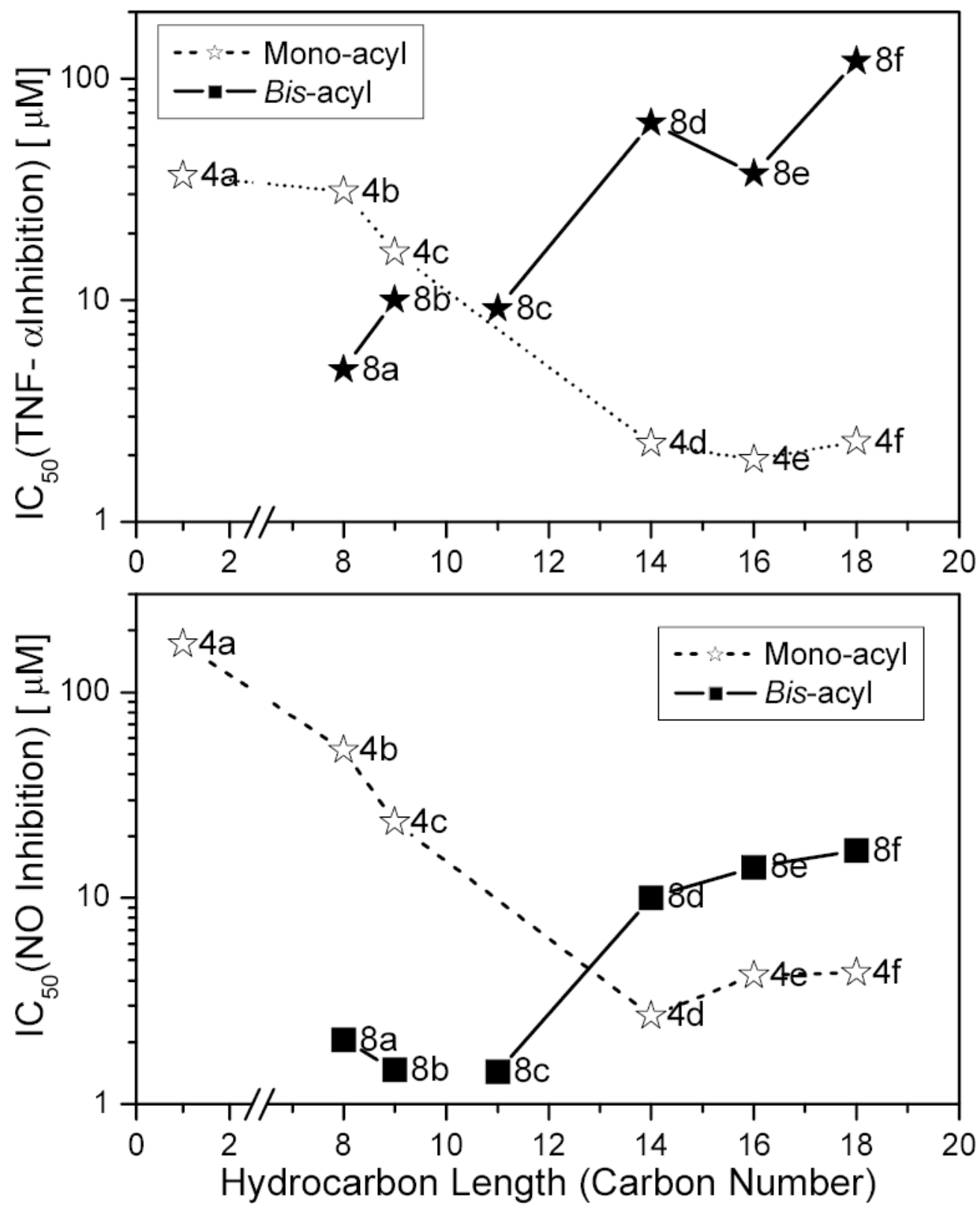

Figure 2.

Correlation between carbon number of the hydrocarbon group in mono- (open stars, dotted line) and bis-acyl (closed stars, solid line) and TNF- $\alpha$ inhibition in human blood (top) and NO inhibition in murine J774A.1 cells (bottom). Data represent means of duplicate values obtained from a representative experiment. 

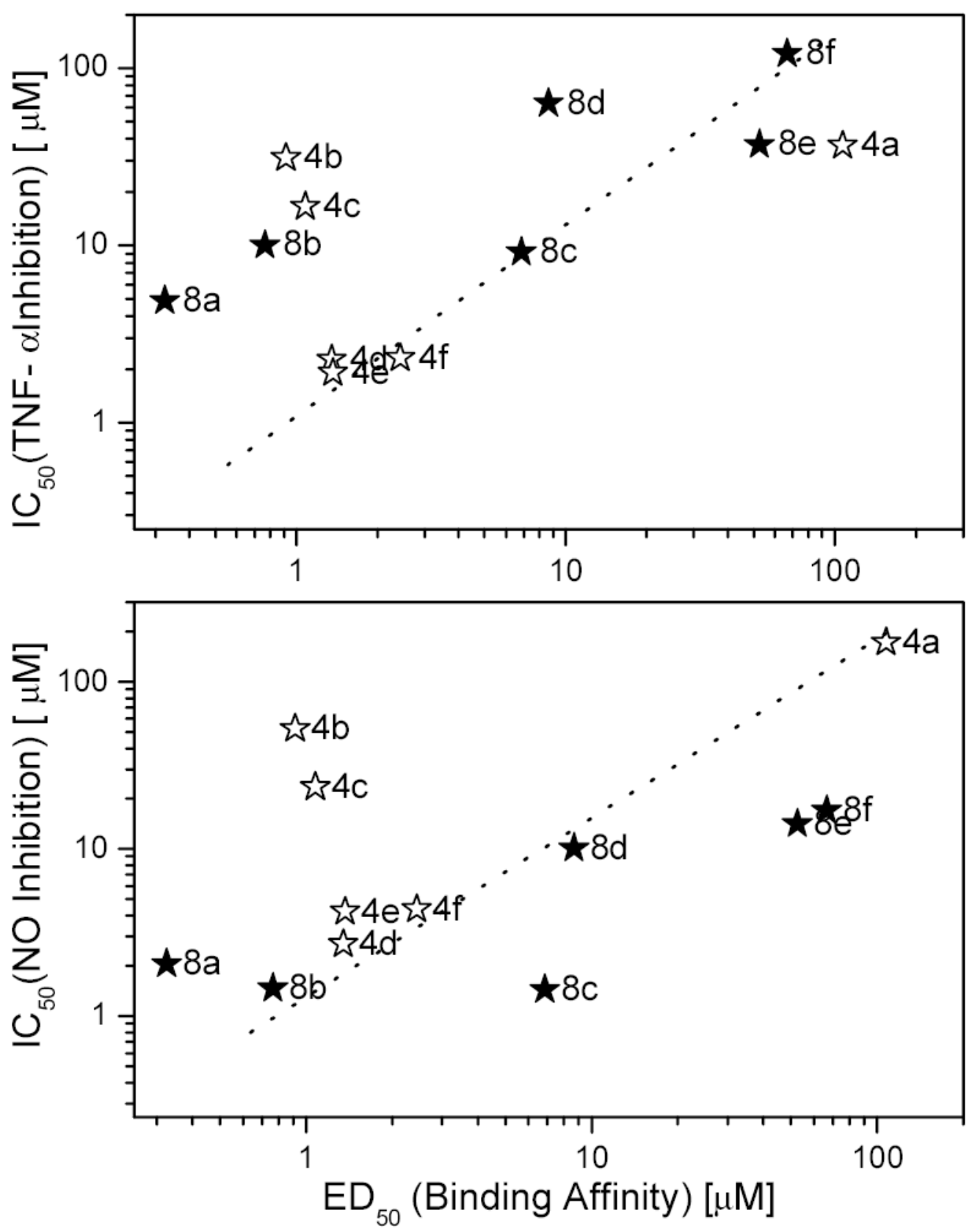

Figure 3.

Correlation of binding affinity of the acylhomospermines determined by $\mathrm{BC}$ fluorescent probe displacement with NO inhibition in murine J774A.1 cells (Bottom) and TNF- $\alpha$ inhibition in human blood (Top). Data represent means of duplicate values obtained from a representative experiment. 

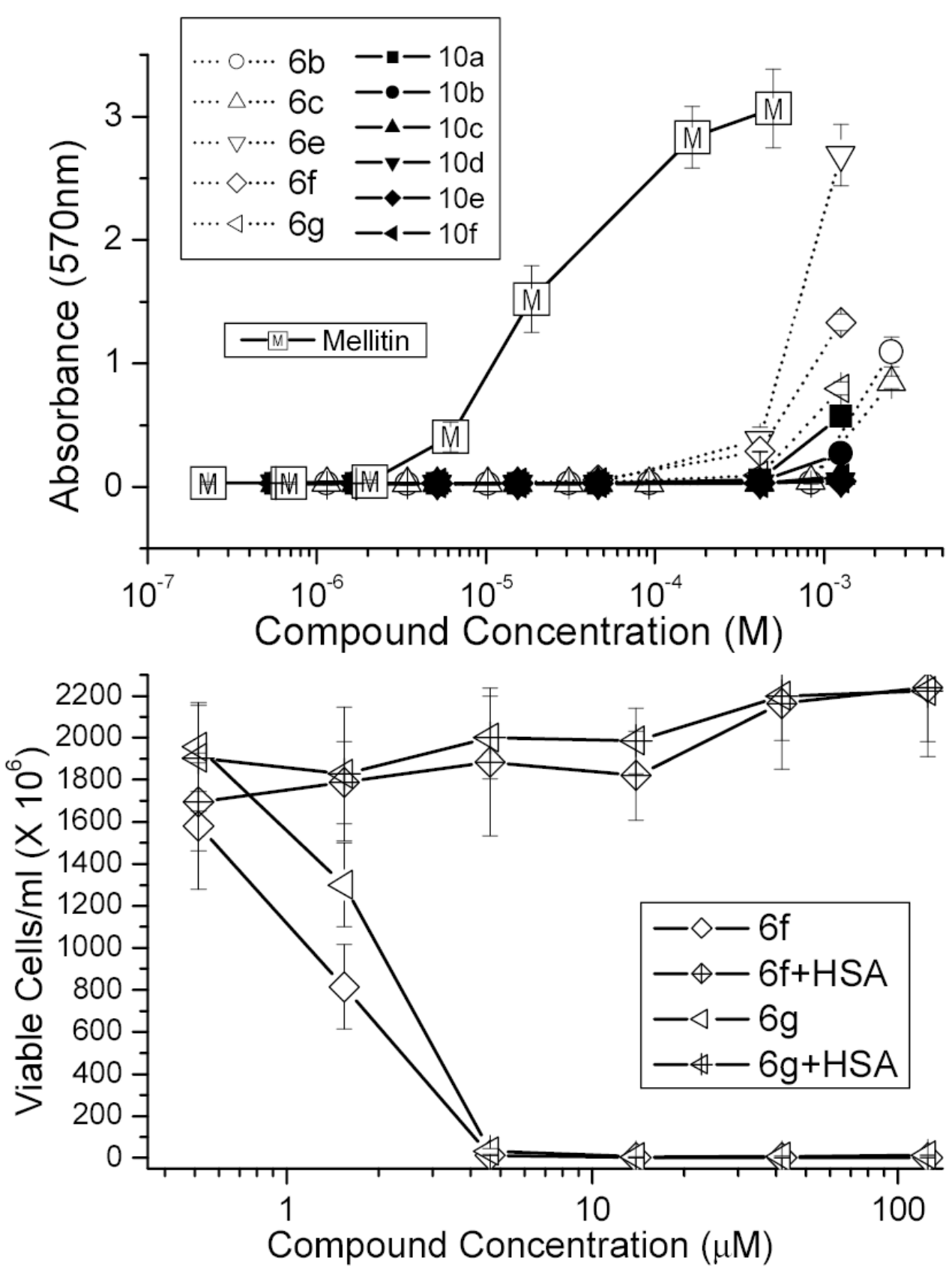

Figure 4.

Hemolytic activity of mono- and bis-acyl homologated spermines in whole human blood (Top) and the effect of addition of human serum albumin $(650 \mu \mathrm{M})$ on the hemolysis of 1:1000 diluted, washed, human erythrocytes, determined by automated video microscopy (Bottom). 


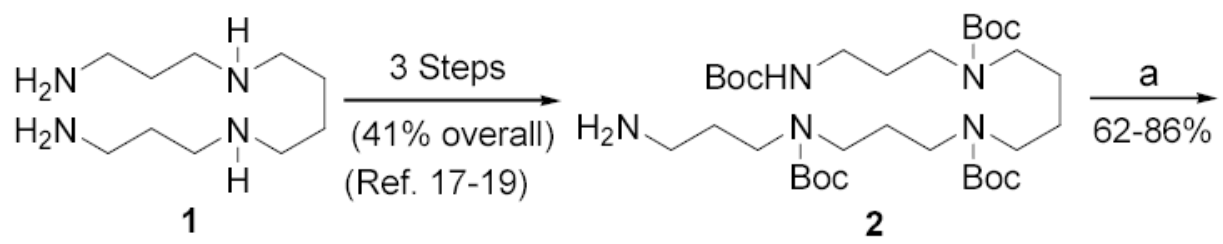

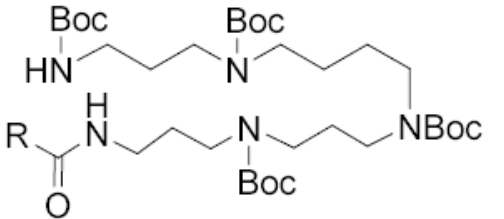

3a, $\mathrm{R}=\mathrm{CH}_{3} ; 3 \mathbf{b}, \mathrm{R}=\mathrm{C}_{8} \mathrm{H}_{17}$;

3c, $\mathrm{R}=\mathrm{C}_{9} \mathrm{H}_{19} ; 3 \mathbf{d}, \mathrm{R}=\mathrm{C}_{14} \mathrm{H}_{29}$;

$3 e, R=\mathrm{C}_{16} \mathrm{H}_{33} ; \mathbf{3 f}, \mathrm{R}=\mathrm{C}_{18} \mathrm{H}_{37}$
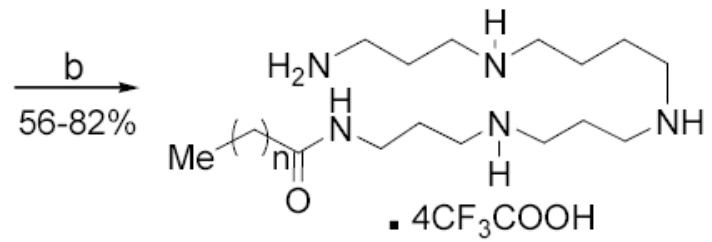

4a, $\mathrm{n}=0 ; \mathbf{4 b}, \mathrm{n}=7 ; \mathbf{4 c}, \mathrm{n}=8$;

$\mathbf{4 d}, \mathrm{n}=13 ; \mathbf{4 e}, \mathrm{n}=15 ; \mathbf{4 f}, \mathrm{n}=17$

Scheme 1.

Reagents: (a) $\mathrm{Ac}_{2} \mathrm{O}$, py, DMAP, rt. (for 3a), or, RCOCl, DMAP, py, rt. (for 3b-c), or, RCOOH, EDCI, THF, 10 h (for 3d-f); (e) TFA, rt., 8 h. 


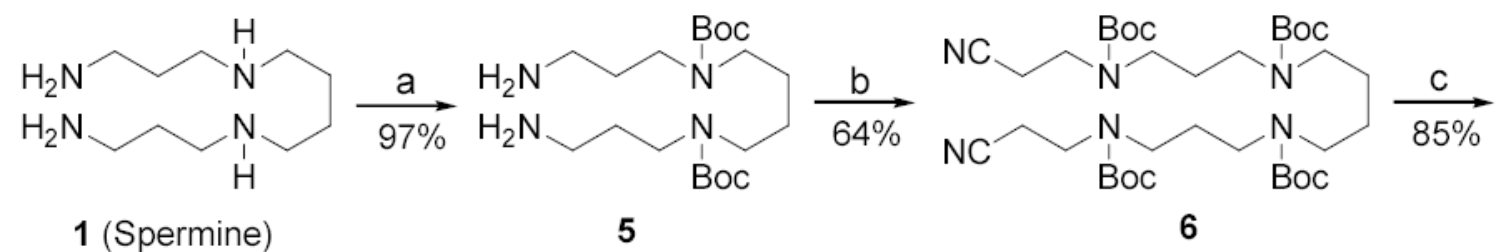

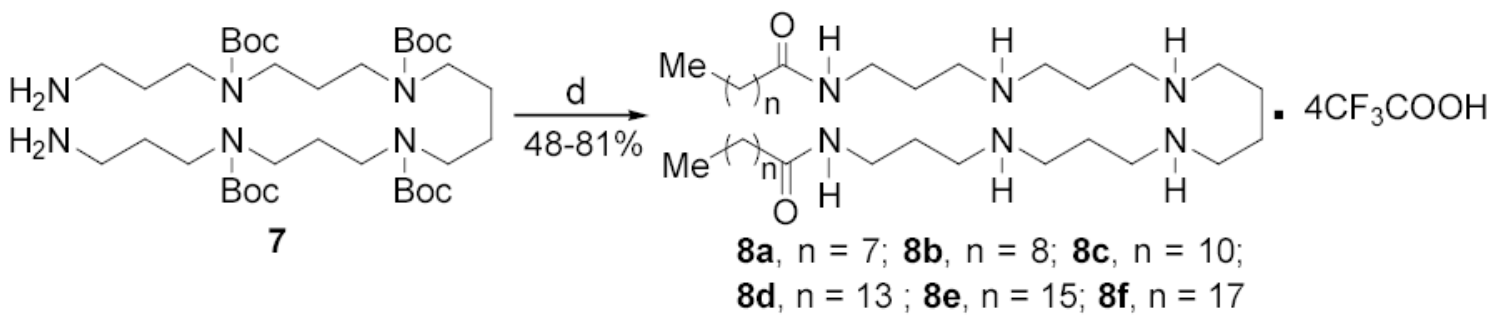

Scheme 2.

Reagents: (a) i. $\mathrm{F}_{3} \mathrm{CCOOEt}$ (2 eq.), $\mathrm{MeOH},-78$ to $0 \mathrm{oC}, 1 \mathrm{~h}$. ii. $\mathrm{Boc}_{2} \mathrm{O}$ (excess), 0 to rt, $1 \mathrm{~h}$. iii. aq. $\mathrm{MeOH}, \mathrm{NH}_{3}$, rt. 25 h.; (b) i. $\mathrm{H}_{2} \mathrm{C}=\mathrm{CHCN}, \mathrm{MeOH}$, rt., 15 h. ii. $\mathrm{Boc}_{2} \mathrm{O}, \mathrm{CH}_{2} \mathrm{Cl}_{2}, 90$ min.; (c) $\mathrm{Pd}(\mathrm{OH})_{2} / \mathrm{C}, \mathrm{H}_{2}, \mathrm{AcOH}, 50$ psi.(d) i. RCOOH, EDCI, THF, 10 h. ii. TFA, rt, $8 \mathrm{~h}$ 
Table 1

Summary of binding affinities and in vitro biological activity (NO and TNF- $\alpha$ inhibition). The Z' factor of the HTS assay for quantifying $\mathrm{ED}_{50}$ (relative binding affinity) is 0.82 , and the CVs at $0 \%$ and $100 \%$ probe displacement are $4.1 \%$ and $6.2 \%$, respectively.56 The CVs for NO and TNF- $\alpha$ inhibition assays, are, respectively, $3.2 \%$ and $4.7 \%$.

\begin{tabular}{|c|c|c|c|c|}
\hline ID & STRUCTURE & $\begin{array}{l}\text { ED50 } \\
(\mu \mathrm{M})\end{array}$ & $\begin{array}{c}\text { NO IC50 } \\
(\mu \mathrm{M})\end{array}$ & $\begin{array}{l}\text { TNF- } \alpha \\
\text { IC50 } \\
(\mu \mathrm{M})\end{array}$ \\
\hline $8 a$ & & 0.33 & 2.05 & 4.88 \\
\hline $8 \mathrm{~b}$ & & 0.76 & 1.47 & 10.03 \\
\hline 4b & & 0.92 & 52.45 & 31.12 \\
\hline $4 c$ & & 1.08 & 23.46 & 16.49 \\
\hline $4 d$ & & 1.35 & 3.69 & 2.27 \\
\hline $4 e$ & & 1.37 & 4.22 & 1.91 \\
\hline $4 f$ & & 2.44 & 4.35 & 2.31 \\
\hline $8 c$ & & 6.87 & 1.44 & 9.19 \\
\hline $8 d$ & & 8.67 & 10.10 & 63.09 \\
\hline $8 \mathrm{e}$ & & 52.53 & 14.18 & 37.10 \\
\hline $8 f$ & & 66.73 & 13.93 & 120.27 \\
\hline 4a & & 107.45 & 171.41 & 36.56 \\
\hline
\end{tabular}


Table 2

Dose-dependent protection of CF-1 mice challenged with a supralethal dose of $200 \mathrm{ng} / \mathrm{mouse}\left(\mathrm{LD}_{100}=100 \mathrm{ng}\right)$ by the acylhomospermines in cohorts of five animals. Lethality was recorded at $24 \mathrm{~h}$ post-challenge. Ratios denote dead/total. Asterixes indicate statistically significant values, $\mathrm{p}<0.05$.

\begin{tabular}{|c|c|c|c|}
\hline Compound Dose ( $\mu \mathrm{g} /$ mouse) & $4 e$ & $\begin{array}{c}\text { Compound } \\
\mathbf{8 a}\end{array}$ & $8 c$ \\
\hline 200 & $0 / 5^{*}$ & $1 / 5^{*}$ & $1 / 5^{*}$ \\
\hline 100 & $0 / 5^{*}$ & $4 / 5$ & $2 / 5$ \\
\hline 50 & $2 / 5$ & $5 / 5$ & $4 / 5$ \\
\hline 10 & $5 / 5$ & $5 / 5$ & $4 / 5$ \\
\hline 0 & $5 / 5$ & $5 / 5$ & $5 / 5$ \\
\hline
\end{tabular}


Table 3

Time-course of protection afforded by $\mathbf{4 e}$ in the D-galactosamine sensitized CF-1 mouse lethality model. Animals were injected with $200 \mathrm{mg}$ 4e i.p. at times noted with respect to LPS challenge ( $200 \mathrm{ng} / \mathrm{mouse})$. Lethality was recorded at $24 \mathrm{~h}$ following LPS challenge. Asterixes indicate statistically significant values, $\mathrm{p}<0.05$.

\begin{tabular}{ccc}
\hline Time of 4e Administration & Lethality (dead/total) \\
\hline$-6 \mathrm{~h}$ & $1 / 5^{*}$ \\
$-4 \mathrm{~h}$ & $1 / 5^{*}$ \\
$-2 \mathrm{~h}$ & $0 / 5^{*}$ & $0 / 5^{*}$ \\
$0 \mathrm{~h}$ & $5 / 5$ \\
$+1 \mathrm{~h}$ & $4 / 5$ \\
\hline
\end{tabular}

